\title{
REASONABLE PATENT EXHAUSTION
}

\section{Herbert Hoven kamp ${ }^{\dagger}$}

A lengthy tug of war between the Supreme Court and the Federal Circuit Court of Appeals may have ended with Impression Products v. Lexmark. The Supreme Court held that the sale of a patented thing exhausts the patentee seller's rights to enforce restrictions on that thing through patent infringement suits. Further, the parties cannot bargain around this rule through the seller's specification of conditions, no matter how clear. No inquiry need be made into the patentee's market power, anticompetitive effects, or other types of harms, whether enforcement of the condition is socially costly or valuable, or whether the condition has a positive or negative impact on innovation. None of this is relevant.

Impression Products reveals an economic deficiency that manifests all too frequently when patent law is brought to bear on market practices. Economic concepts that are commonly used in antitrust law, such as market power or output effects, are virtually unknown in patent law. This fact has inclined courts to go to wild extremes-such as equating every patent with monopoly, or concluding that a patent is a mere property right and that anything done within the scope of the patent is permissible. The result, as in this case, can be draconian rules that are indifferent to effects on innovation, competition, economic efficiency, or any other measure that seems relevant to innovation policy. This Article argues that the Supreme Court would have been wise to develop a more nuanced exhaustion rule that examined actual effects likely to result from a particular restraint.

Introduction: Patents and Patented Things.................................................514

I. Policy Concerns and Economic Effects ....................................................5.516

II. Rationales ....................................................................................5522

A. Retroactive Extensions of the Patent Term............................523

B. Distinguishing Unconditional from Conditional Licenses ............527

C. Trading Off Duration and Enforcement Scope ............................529

D. Preserving Room for the Law of Patented Things-Concerns for

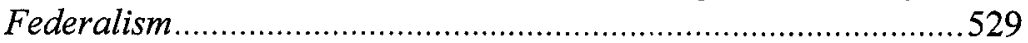

E. Competition Concerns Rationalizing Exhaustion........................532

$\dagger \quad$ James G. Dinan University Professor, Penn Law and Wharton Business, University of Pennsylvania. Thanks to participants in a Penn Law workshop and Erik N. Hovenkamp for helpful feedback. 


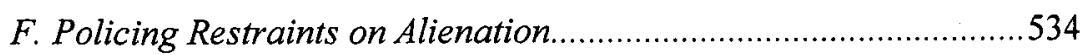

III. Implications and Reach .................................................................538

A. Standard-Essential Patents (SEPs)-Reversal of Incentives..........539

B. Exhaustion, Tying, and Misuse.............................................542

C. Tying and the Patent Misuse Reform Act .................................543

IV. Assessing Unreasonable Patent Exhaustion........................................545

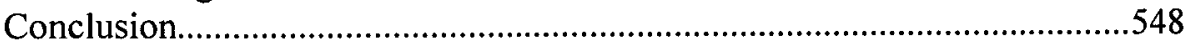

Introduction: Patents and Patented Things

A lengthy tug of war between the Supreme Court and the Federal Circuit Court of Appeals very likely ended when the Supreme Court held that the sale of a patented article exhausts the patentee seller's right to enforce restrictions on that article through a patent infringement suit. ${ }^{1}$ Further reversing the Federal Circuit, the Court found that parties cannot bargain around this rule through the seller's specification of conditions stated at the time of sale, no matter how clear. ${ }^{2}$ That is, once a sale of the patented article has occurred, the rule is not merely presumptive, but absolute. In this Article, I argue that this categorical approach to patent exhaustion is a mistake that furthers neither patent and innovation policy, nor competition policy.

The patent first sale, or "exhaustion," rule applies not to patents themselves but rather to the sale of patented "things." To illustrate, if the patentee grants a production license to an office stapler manufacturer, authorizing it to employ its patented technology in its stapler, no "thing" is being sold. As a result, a limitation on where the patented stapler can be manufactured, in what amount, what the resale price will be, ${ }^{3}$ or whether the manufacturer must bundle it prior to sale with the patentee's staples is ordinarily enforceable insofar as patent law is concerned. If the patentee or licensee produces a stapler embodying the patented technology and then sells it, however, exhaustion becomes relevant for any restriction to be enforced on that particular stapler subsequent to the sale. The distinction is not between the presence or absence of a license. The purchaser of a patented office stapler automatically receives an implied license to practice embodied patents to the extent of using the stapler. ${ }^{4}$ That implied license does not give the purchaser a right to make more copies of the stapler. With respect to the stapler that the buyer actually purchases, however, the exhaustion rule says

1. Impression Prods., Inc. v. Lexmark Int'l, Inc., 137 S. Ct. 1523 (2017).

2. Id.

3. For example, under the "GE" rule a patentee can license a competing firm to manufacture the patented article and specify the price at which it is to be sold. United States v. Gen. Elec. Co., 272 U.S. 476 (1926).

4. Aro Mfg. Co. v. Convertible Top Replacement Co., 377 U.S. 476, 497 (1964); see also Dawson Chem. Co. v. Rohm \& Haas Co., 448 U.S. 176, 184 (1980) (speaking of the "'implied" licenses conferred by operation of law upon purchasers" of its patented product). 
that the patentee may not by patent license impose conditions on the stapler's subsequent use or sale and enforce these conditions through a patent infringement suit.

For example, suppose the patentee sells a stapler at wholesale to Office Depot and requires Office Depot to charge at least $\$ 15.00$ to customers. That condition cannot be enforced by a patent infringement lawsuit; although, it probably could be enforced by a breach of contract action. ${ }^{5}$ The contract lawsuit can ordinarily be brought only against those in privity of contract with the patentee, however. By contrast, if an infringement action were permitted, it could be brought against everyone who violates the condition, whether or not they are in privity or have ever agreed to be bound by the contract's terms. Other differences could be important as well. For example, the patent infringement action can be maintained only in federal court under federal law, while the breach of contract action is ordinarily governed by state law. ${ }^{6}$

Further, because the question of patent infringement is federal, it would override conflicting state policies. For example, suppose that resale price maintenance (RPM) were unlawful under state antitrust law, ${ }^{7}$ but that patent law permitted a post-sale infringement action against someone who violated an RPM condition. In that case, the RPM condition would be enforceable as a matter of federal patent law, thus preempting the state prohibition. ${ }^{8}$ Since virtually anything that can be expressed in a contract can also be expressed as a condition on a sale, abolition of the first sale doctrine could effectively federalize the law of use restrictions on patented things. Of course, the federal antitrust laws would still operate. For example, Section 3 of the Clayton Act prohibits anticompetitive exclusive dealing or tying of goods "whether patented or unpatented."

None of this will happen under the Supreme Court's Impression Products decision, however. The Court stated what amounts to a per se rule: once a patented thing is sold, conditions imposed on that particular thing cannot be enforced via patent infringement suits. No further inquiry is made into the patentee's market power, anticompetitive effects, or other types of harms, whether enforcement of the condition is socially costly or valuable, or has a positive or negative impact on innovation. None of this is relevant.

5. Since 2007, resale price maintenance in the United States has been governed by a rule of reason. Leegin Creative Leather Prods., Inc. v. PSKS, Inc., 551 U.S. 877 (2007). As a result, most instances of it are very likely lawful. PHILLIP E. AREEDA \& HERBERT HOVENKAMP, ANTITRUST LAW ๆ 1620 (4th ed. 2017).

6. See Edwin H. Abbot, Jr., Patents and the Sherman Act, 12 COLUM. L. REV. 709 (1912) (noting jurisdictional differences).

7. States may have their own antitrust laws which are at variance from federal law. See, e.g., O’Brien v. Leegin Creative Leather Prods., Inc., 277 P.3d 1062, 1079 (Kan. 2012) (holding that under Kansas antitrust law RPM remains unlawful per se and noting that "federal precedents interpreting, construing, and applying federal statutes have little or no precedential weight when the task is interpretation and application of a clear and dissimilar Kansas statute").

8. See Herbert Hovenkamp, Patent Exhaustion and Federalism: A Historical Note, 102 VA. L. REV. ONLINE 25 (2016).

9. 15 U.S.C. $\S 14(2018)$ 
Part I of this Article explores the economic concerns and effects of the Supreme Court's exhaustion rule. Part II turns to the rationales that have been offered for it, concluding that none of them justifies the draconian rule that the Supreme Court adopted. Part III looks at some of the implications of the harsh exhaustion rule. Part IV then makes some proposals for a more nuanced approach to patent exhaustion. A brief conclusion follows.

\section{Policy Concerns and Economic Effects}

The Impression Products decision reveals an economic deficiency that manifests all too frequently when patent law is brought to bear on market practices. Patent law has never developed tools for evaluating such practices. Economic concepts such as market power, output effects, or effects on innovation, which are commonly used in economics and antitrust law, are virtually unknown in patent law. This fact has inclined the Court to go to wild extremes - such as equating every patent with monopoly, as it has often done, ${ }^{10}$ or concluding that a patent is a mere property right and that anything done within the scope of the patent should therefore be permissible. ${ }^{11}$ Too often, this produces extreme rules that are indifferent to effects on innovation, competition, economic efficiency, or any other measure that seems relevant to innovation policy. The exhaustion rule in Impression Products is an example.

Patent exhaustion cannot be found in the Patent Act or any other federal statute. It is entirely judge made. It is particularly important that judge-made deviations from a statute have an articulated policy. Statutes can be the consequence of politics or capture, or perhaps they are badly drafted. An important rationale for judge-made deviations from a statute is to set things right or else fill statutory gaps. In this case, the Intellectual Property (IP) Clause of the Constitution authorizes Congress to create a patent act in order to promote innovation. ${ }^{12}$ This Article therefore assumes that a judge-made exhaustion rule must reflect that purpose. An innovation-promoting rationale for the per se patent exhaustion rule is hard to find, however. To be sure, some post-sale restraints can be anticompetitive, and practices that restrain trade can also restrain innovation. ${ }^{13}$ But the collective set of practices that have been subjected to patent exhaustion hardly falls naturally into that category.

10. E.g., Int'l Salt Co. v. United States, 332 U.S. 392 (1947) (concluding that market power could be inferred from the existence of a patent), overruled by Ill. Tool Works, Inc. v. Indep. Ink, Inc., 547 U.S. 28 (2006); Carbice Corp. of Am. v. Am. Patents Dev. Corp., 283 U.S. 27 (1931) (speaking repeatedly of the patent monopoly).

11. E.g., FTC. v. Actavis, Inc., 133 S. Ct. 2223, 2238 (2013) (Roberts, C.J., dissenting) (arguing that a restraint should be reasonable if it is within the scope of the patent); see also Herbert Hovenkamp, The Rule of Reason and the Scope of the Patent, 52 SAN DIEGO L. REV. 515 (2015) (arguing against expansive use of "scope of the patent" immunity from antitrust law).

12. U.S. CONST. art. I, \& 8, cl. 8 (granting the Congress the power "to promote the progress of science and useful arts").

13. See Herbert Hovenkamp, Restraints on Innovation, 29 CARDOZO L. REV. 247 (2007) 
Post-sale restraints are generally "vertical." They operate as between a seller and a buyer, and typically not between competing sellers or competing buyers. After decades of litigation under the antitrust laws, courts have concluded that vertical restrictions should be treated more benignly than horizontal agreements involving competitors. Restrictions of the kind subject to patent exhaustion can be both socially harmful and socially beneficial. Establishing which of these is true ordinarily requires a detailed inquiry into market power and effects that antitrust law denominates "the rule of reason."14 Indeed, the overwhelming trend in antitrust jurisprudence over the last forty years has been to move away from per se rules for vertical restraints and toward a rule of reason. ${ }^{15}$

So why should the patent exhaustion rule be so draconian? One commonly given explanation is that most antitrust cases involving vertical restraints are limitations on breach of contract suits, not on patent infringement actions. That is certainly a distinction, but is it one that bears the weight now given to it? Permitting some enforcement actions via infringement suits can be socially valuable when (1) the restriction at issue is economically beneficial, but (2) breach of contract actions are not an adequate enforcement device.

Consider Impression Products itself. Printer manufacturer Lexmark sold its Lexmark-specific ink (toner) cartridges at a discount, provided the buyer agreed in advance to use the cartridge only once and then return the empty cartridge to Lexmark. ${ }^{16}$ Lexmark's intent was not in controversy: it wished to dry up a secondary market for spent cartridges that firms such as Impression Products could then refill and sell, often at prices that were a small fraction of the amount that Lexmark charged for a new cartridge.

In antitrust terms, the practice that Lexmark was attempting to enforce was a variable proportion tying arrangement, sometimes referred to as a metering tie. In such a tie, the buyer purchases one copy of a "tying" product, such as a printer, but then uses varying amounts of some secondary "tied," product, such as toner cartridges. Under a tie, printer purchasers would be required to purchase cartridges from Lexmark rather than from independent firms who refurbish used cartridges. The tying firm typically drops the price of the tying product, sometimes to zero, but raises the price of the tied product. ${ }^{17}$ Today the general, although not unanimous, consensus among antitrust economists is that variable proportion tying agreements are devices for facilitating second degree price

14. See Herbert Hovenkamp, The Rule of Reason, 70 FLA. L. REV. (forthcoming 2018).

15. E.g., Leegin Creative Leather Prods., Inc. v. PSKS, Inc., 551 U.S. 877 (2007) (holding resale price-maintenance, sometimes known as vertical price fixing, to be governed by rule of reason); NYNEX Corp. v. Discon, Inc., 525 U.S. 128 (1998) (holding purely vertical concerted refusal to deal, as opposed to horizontal refusal, to be governed by rule of reason).

16. Impression Prods., Inc. v. Lexmark Int'l, Inc., 137 S. Ct. 1523 (2017).

17. See Erik N. Hovenkamp \& Herbert Hovenkamp, Tying Arrangements and Antitrust Harm, 52 ARIZ. L. REV. 925, 943 (2010); see also Siegel v. Chicken Delight, Inc., 448 F.2d 43, 46-47 (9th Cir. 1971) (considering tying by minor fast food franchisor with franchise fee of zero). 
discrimination, that they typically result in increased output, and that the welfare gains that they produce exceed losses, perhaps by a wide margin.

More particularly, the practice produces two positive welfare effects on consumers and one negative one. First, the reduction in the price of the tying product (printers) increases its output by bringing in additional buyers who would not be in the market otherwise. Second, low intensity users gain more from the price cut in the tying product than the price increase in the tied product (toner cartridges). Offsetting this, high intensity users end up paying more. The aggregate price increase on the cartridges they buy exceeds the price cut on the printer.

How harms and benefits net out is an empirical question and depends on the amount of market power the tying firm enjoys in the tying product. ${ }^{18}$ The practice can be shown to reduce welfare only if the seller is a monopolist or perhaps is colluding with others to impose the tie. ${ }^{19}$ The one article finding a significant possibility of welfare harm assumes a defendant with a monopoly in the tying product and a perfectly competitive tied product. ${ }^{20}$ It finds a possible reduction in welfare by assuming the existence of a large set of higher intensity purchasers, as described above, who are subjected to the tying arrangement even though it makes them worse off. The overall effect of the tie is negative if the welfare loss suffered by these purchasers is greater than the gains experienced by those who benefit from either the tying product output increase or the price cut in the tied product.

In a perfectly competitive tying market, this set would be empty, however. Those asked to subject themselves to a costly tie would simply buy their products from a rival. In that case, the tie would be an unambiguous welfare gain. The seller's additional profits would come entirely from the increase in tying product output.

The markets in which tying occurs are almost never monopolized; although, they are not perfectly competitive either. Most are product differentiated and at least moderately competitive. For example, Lexmark is a relatively minor player in the highly competitive but differentiated consumer market for laser printers. Its share was less than five percent, making it significantly smaller than rivals Hewlett-Packard, Epson, Canon, and Brother. ${ }^{21}$ In such a market, all those customers who gain from the tie will be likely to stay

18. See Hovenkamp \& Hovenkamp, supra note 17 , at $937-940 ;$ cf. Einer Elhauge \& Barry Nalebuff, The Welfare Effects of Metering Ties, 33 J.L. ECON. \& ORG. 68 (2017) (arguing that such ties can reduce welfare in some circumstances when the seller is a tying product monopolist). In fact, however, tying product monopolists are a rarity in the antitrust law of variable proportion ties. See Herbert Hovenkamp, Antitrust and the Design of Production, 103 CORNELL L. REV. (forthcoming 2018).

19. E.g., Elhauge \& Nalebuff, supra note 18 (speaking repeatedly of defendant as a "price-discriminating monopolist").

20. Id.

21. See "Weak Demand" for Printers and Cartridges Affects Lexmark, RECYCLER (Dec. 10, 2015), http://www.therecycler.com/posts/weak-demand-for-printers-and-cartridges-affectslexmark/ [http://perma.cc/29YP-XJ6D] (estimating 4.5 percent). 
in unless a rival promises even greater gains. Those for whom the tie is costly will seek out an alternative, which will not be difficult to find. ${ }^{22}$ As a result, a necessary but not sufficient condition for consumer harm from a variable proportion tie is very significant market power in the tying product market. The market must be sufficiently noncompetitive that buyers upon whom the tie imposes losses are forced to remain subject to the tie, and their losses must outweigh the gains that accrue to others.

Given Lexmark's market share, its printer-cartridge tie was almost certainly welfare increasing. At the very least, it was sufficiently ambiguous that further inquiry into market power and competitive effects would be essential to answering the welfare question. The Supreme Court itself recognized, however, that it would be difficult or impossible for Lexmark to enforce a tying condition imposed directly on consumers via breach of contract suits. ${ }^{23}$ Lexmark had even attempted to use a microchip pairing of printer and cartridge in order to prevent use of competitors' cartridges, but the Sixth Circuit had refused to find copyright violations by rivals who duplicated or invented around the chips. ${ }^{24}$ While one might get purchasers of printers to agree not to use anything but Lexmark's own cartridges, there is no effective means for Lexmark to discover violations and enforce such a contract.

By contrast, the refilling companies, such as infringement defendant Impression Products, are fewer and must sell in publicly accessible places such as Amazon. They could therefore be identified. However, they are not in privity of contract with Lexmark. As a result, the ability to turn a violation of the tying clause into a patent infringement suit was very likely the only effective mechanism Lexmark had for enforcing its tie. With a properly posted notice, Lexmark could warn Impression Products and other refillers that their activity constituted patent infringement.

Thus, the Supreme Court's decision very likely prevented Lexmark from using a socially valuable device that could be expected to lower the cost of owning and operating computer printers. ${ }^{25}$ In the Kirtsaeng case, which involved copyright law's statutory first sale doctrine, Justice Breyer's majority opinion advocated that competition policy be brought to bear. He noted Lord Coke's seventeenth-century statement that post-sale restraints are "against Trade and Traffique, and bargaining and contract," and located these concerns within

22. For example, Amazon carries thirteen brands of computer printers, including all of the major ones-Canon, HP, Epson, Brother, Xerox, and Lexmark. See AMAZON, http://amazon.com [http://perma.cc/P6WY-2AQJ] (search "printers").

23. See Impression Prods., 137 S. Ct. at 1528-30 (detailing the history of Lexmark's attempts to enforce the tie by mechanisms other than patent infringement actions).

24. Lexmark Int'l, Inc. v. Static Control Components, 387 F.3d 522 (6th Cir. 2004) (holding that defendant's anticircumvention technology did not violate DMCA and, in any event, qualified for the DMCA's interoperability defense (citing 17 U.S.C. $\$ 1201$ (f)(3) (2018)).

25. Because customers want printing services the proper cost is the combination of printer and cartridges that the customer uses, not of printers alone or cartridges alone. That is, the two are strong complements. 
competition law. ${ }^{26}$ Justice Breyer's rationale for the first sale doctrine emphasized "the importance of leaving buyers of goods free to compete with each other when reselling or otherwise disposing of those goods." For that proposition, he cited an antitrust case and an antitrust treatise. ${ }^{27}$ By contrast, in Impression Products Chief Justice Roberts quoted the same passage from Lord Coke, ${ }^{28}$ but emphasized its relationship to the common law's hostility toward restraints on the alienation of chattels, citing both Coke's Institutes and John Chipman Gray's treatise on that subject. ${ }^{29}$

Seventy years after the Supreme Court applied the first sale doctrine to copyright, ${ }^{30}$ Congress codified the doctrine in a revised Copyright Act. $^{31}$ Although the patent first sale doctrine is much older, ${ }^{32}$ Congress has never done the same thing in the Patent Act. Two statutes have spoken to the issue of patent exhaustion, and then only indirectly. One is Section 3 of the Clayton Act, an antitrust provision passed in response to the Supreme Court's 1912 Henry decision. The other, discussed later, is the Patent Misuse Reform Act. ${ }^{33}$

In Henry, the Supreme Court recognized an exception to the first sale doctrine for "conditional" sales, just as the Federal Circuit had been doing prior to Impression Products. ${ }^{34}$ Writing for the Court, Justice Lurton explained that the sale of a patented thing could be either unconditional or conditional. If it was unconditional, then the exhaustion rule applied. By means of a conditional sale, however, the patentee could "sever" any indicia of ownership that it wished, for severability was inherent in the nature of a property right. ${ }^{35}$

The Henry Court then went on to approve enforcement of a variable proportion tying arrangement via a patent infringement action, on facts quite similar to those in Impression Products. Patentee A.B. Dick, a large

26. Kirtsaeng v. John Wiley \& Sons, Inc., 568 U.S. 519, 538 (2013) (quoting 1 EDWARD COKE, INSTITUTES OF THE LAWES OF ENGLAND \$ 360, at 223 (1628)).

27. Id. (citing Leegin Creative Leather Prods., Inc. v. PSKS, Inc., 551 U.S. 877, 886 (2007); and 1 PHILLIP E. AREEDA \& HERBERT HOVENKAMP, ANTITRUST LAW $\$ 100$, at 4 (3d ed. 2006))

28. Impression Prods., 137 S. Ct. at 1526.

29. Id. (citing JOHN CHIPMAN GRAY, RESTRAINTS ON THE ALIENATION OF PROPERTY $\S 27$, at $18(2 \mathrm{~d}$ ed. 1895$)$ ).

30. Bobbs-Merrill Co. v. Straus, 210 U.S. 339, 343 (1908) (judge-made exhaustion rule for printed, copyrighted book, relying on patent exhaustion cases).

31. Copyright Act of 1976,17 U.S.C. $\$ 109$ (2018).

32. Dating to Bloomer v. McQuewan, 55 U.S. (14 How.) 539 (1852).

33. See infra notes 159-164 and accompanying discussion.

34. E.g. Lexmark Int'l, Inc. v. Impression Prods., Inc., 816 F.3d 721 (Fed. Cir. 2016) (refusing to apply exhaustion to a conditional sales contract), rev'd, Impression Prods., Inc. v. Lexmark Int'l, Inc., 137 S. Ct. 1523 (2017); Mallinckrodt, Inc. v. Medipart, Inc., 976 F.2d 700 (Fed. Cir. 1991) (similar), overruled by Impression Products, 137 S. Ct. 1523.

35. See Henry v. A.B. Dick Co., 224 U.S. 1, 24-25 (1912) ("The property right to a patented machine may pass to a purchaser with no right of use, or with only the right to use in a specified way, or at a specified place, or for a specified purpose. The unlimited right of exclusive use which is possessed by and guaranteed to the patentee will be granted if the sale be unconditional. But if the right of use be confined by specific restriction, the use not permitted is necessarily reserved to the patentee. If that reserved control of use of the machine be violated, the patent is thereby invaded. This right to sever ownership and use is deducible from the nature of a patent monopoly and is recognized in the cases."). 
manufacturer of office equipment, sold its patented mimeograph copy machine subject to a clearly printed license restriction attached to each copy of the machine. The restriction stated that the machine could be used only with paper, ink, and stencils supplied by A.B. Dick itself. ${ }^{36}$ Because the notice was prominently attached to each machine, one could reasonably expect it would be communicated to subsequent users, whether or not they were in privity of contract with the patentee. Henry was a office supply store operator who sold a can of ink to a purchaser of the machine, knowing that the purchaser intended to use it in violation of A.B. Dick's condition. ${ }^{37}$

The Supreme Court concluded that exhaustion did not apply to clearly conditional sales. Neither could it find anything in the Sherman Act, which had been passed twenty-two years earlier, that spoke to the patent licensing practice at issue.$^{38}$ As a result, neither patent law nor antitrust law prevented enforcement of the tie. Henry was only one of many decisions that applied patent exhaustion selectively, depending on whether the sale of the patented good was conditional or unconditional, ${ }^{39}$ but often paying little attention to the nature of the restriction that the condition imposed. For its part, the Federal Circuit adhered to the conditional use distinction, even after the Supreme Court appeared to overrule it in its Quanta decision. ${ }^{40}$ Precision Products clearly has brought that to an end.

Whether the drafters of the Sherman Act had intended for the statute to apply to patent ties is doubtful. The statute never mentions patents. Nevertheless, Congress was clearly unhappy with the Henry decision. It responded, however,

36. See id. at 11:

License Restriction.

This machine is sold by the A. B. Dick Company with the license restriction that it may be used only with the stencil paper, ink, and other supplies made by A. B. Dick Company, Chicago, U. S. A.

37. Henry's act was one of "contributory" infringement. Liability for contributory infringement was subsequently (in 1952) narrowed to cover only the sale of things not capable of substantial noninfringing uses. 35 U.S.C. $\$ 271$ (c) (2018). The can of ink in the Henry case almost certainly had substantial noninfringing uses.

38. Henry, 224 U.S. at 30. The Court quoted with approval Justice Peckham's opinion ten years earlier in E. Bement \& Son, Inc. v. National Harrow, Inc., 186 U.S. 70 (1902), that the Sherman Act

clearly does not refer to that kind of a restraint of interstate commerce which may arise from reasonable and legal conditions imposed upon the assignee or licensee of a patent by the owner thereof, restricting the terms upon which the article may be used and the price to be demanded therefor. Such a construction of the act, we have no doubt, was never contemplated by its framers.

Id. at 92 . The Bement decision went on to uphold a price fixing provision contained in a patent crosslicense.

39. E.g, Aro Mfg. Co. v. Convertible Top Replacement Co., 365 U.S. 336, 356 (1961) (dicta approving American Cotton-Tie); Keeler v. Standard Folding Bed Co., 157 U.S. 659, 663 (1895) (applying exhaustion when the patentee "has himself constructed a machine and sold it without any conditions"); American Cotton-Tie Co. v. Simmons, 106 U.S. 89 (1882) (enforcing a restriction explicitly made at the time of sale that metal tie sold for baling cotton could be used only once); Mitchell v. Hawley, 83 U.S. (16 Wall.) 544, 547 (1872) ("without any conditions"); Providence Rubber Co. v. Goodyear, 76 U.S. (9 Wall.) 788, 799 (1870) (refusing to apply exhaustion when the licensee expressly restricted licensee to produce one type of article but licensee produced a different one).

40. Quanta Computer, Inc. v. LG Elecs., Inc., 553 U.S. 617 (2008). 
by amending the antitrust laws. Section 3 of the Clayton Act, which was enacted two years after Henry, made it unlawful to sell a product, "whether patented or unpatented," on the condition that the purchaser not deal in a competitor's goods. Further, it added the language "where the effect may ... be to substantially lessen competition or tend to create a monopoly" - a clear sign that it did not intend to condemn all such tying conditions categorically, but only under a rule of reason that distinguished competitively harmful practices. ${ }^{41}$

The one thing that Congress did not do in response to Henry was amend patent law so as to eliminate patent exhaustion doctrine's distinction between conditional and unconditional sales. Rather, in the eyes of Congress in 1914, addressing the problem of A.B. Dick's tying arrangement was more a question of antitrust policy than patent policy. Further, as an antitrust question, it required an analysis of competitive effects and not a categorical rule that simply condemned every such arrangement categorically. Thus, the most sensible reading of the Congressional response to Henry was that it had no wish to jettison the "condition" distinction for patent exhaustion, but it did want antitrust law to assess competitive effects in order to determine which conditions could be enforced and which could not be. ${ }^{42}$

\section{Rationales}

While competition policy may or may not provide the proper rationale for the first sale doctrine, some policy justifying a purely judicial deviation from an elaborate statute such as the Patent Act seems to be in order. An argument from

41. See Clayton Act $\S 3$, ch. 323, 15 U.S.C. $§ 14$ (2018) ("It shall be unlawful for any person ... to lease or make a sale or contract for sale of goods, wares, merchandise, machinery, supplies, or other commodities, whether patented or unpatented ... on the condition, agreement, or understanding that the lessee or purchaser thereof shall not use or deal in the goods, wares, merchandise, machinery, supplies, or other commodities of a competitor or competitors of the lessor or seller, where the effect of such lease, sale, or contract for sale or such condition, agreement, or understanding may be to substantially lessen competition or tend to create a monopoly in any line of commerce.").

In addition to Section 3 of the Clayton Act, one other statutory provision may be at least remotely relevant to exhaustion, although that is hardly clear. See 35 U.S.C. $\$ 271$ (c) (2018) ("Whoever offers to sell or sells within the United States or imports into the United States a component of a patented machine, manufacture, combination or composition, or a material or apparatus for use in practicing a patented process, constituting a material part of the invention, knowing the same to be especially made or especially adapted for use in an infringement of such patent, and not a staple article or commodity of commerce suitable for substantial noninfringing use, shall be liable as a contributory infringer.").

Under this provision, someone who sold ink for use in an A.B. Dick machine could not be guilty of contributory infringement because the ink is capable of many noninfringing uses. That does not necessarily mean, however, that such a seller could evade the posted license restriction at issue in that case. In any event, the provision was enacted in 1952, forty years subsequent to Henry.

42. The language requiring proof of anticompetitive effects distinguished tying from resale price maintenance (RPM), which was unlawful per se at the time and would remain so for nearly a century. See Dr. Miles Med. Co. v. John D. Park \& Sons Co., 220 U.S. 373 (1911) (holding that resale price maintenance was per se unlawful under antitrust law); Bobbs-Merrill Co. v. Straus, 210 U.S. 339 (1908) (holding that a resale price maintenance condition was unenforceable under copyright exhaustion doctrine). As a result, all RPM agreements were both exhausted, assuming the conditions for exhaustion applied, and unenforceable as breach of contract actions. 
congressional intent seems very weak. In his opinion for the Court in Impression Products, Chief Justice Roberts made something of the fact that Congress has had numerous opportunities to amend the Patent Act so as to eliminate or limit judge made exhaustion, but had never done so. ${ }^{43}$ While factually true, it need not lead to the conclusion that the Chief Justice drew. For example, the Supreme Court created a judge-made exhaustion rule for copyright in 1908 in the BobbsMerrill case. Congress validated that decision nearly seventy years later by making the doctrine statutory. ${ }^{44}$ In the case of the Patent Act, however, Congress has neither statutorily recognized the doctrine nor statutorily repudiated it. So one could as easily conclude that it was indifferent. It is also clear that Congress has never responded to the "conditional" sales distinction that has appeared repeatedly in the cases, including Henry. In fact, for tying cases, Congress subsequently embraced it. ${ }^{45}$ In sum, one cannot conclude from congressional behavior that Congress wanted the absolute exhaustion rule that Impression Products developed.

Further, the one policy rationale on which the Impression Products Court rested-a policy against restraints on alienation-seems poorly suited to the situation, for reasons to be discussed later. ${ }^{46}$ Prior to that, many of the Supreme Court's first sale decisions stated a rationale, but these were often quite different from one another. The rationales were as follows.

\section{A. Retroactive Extensions of the Patent Term}

The first decision to apply the patent exhaustion rule, Bloomer $v$. McQuewan, had a clear and principled rationale which was followed in one subsequent case and then abandoned because it was so specific to particular legislative facts. ${ }^{47}$ The patentee, William Woodworth, owned a very important patent on a wood planing machine, which was also one of the most frequently litigated patents in the nineteenth century. ${ }^{48}$ As the patent neared its expiration, Woodworth lobbied Congress and received a retroactive extension of the patent term in the 1836 Patent Act. ${ }^{49}$ Woodworth died in 1839 , but his son was able to obtain a second extension in an Act of Congress that applied only to his patent,

43. Impression Prods., Inc. v. Lexmark Int'l, Inc., 137 S. Ct. 1523, 1536 (2017).

44. 17 U.S.C. $\$ 109$ (2018).

45. See discussion infra text at notes 158-163.

46. See discussion infra notes 109-134.

47. Bloomer v. McQuewan, 55 U.S. (14 How.) 539 (1852).

48. On the importance of the Woodworth planning patent, see Herbert Hovenkamp, Emergence of Classical Patent Law, 58 ARIZ. L. REV. 263, 289-291 (2016), and see also Carolyn C. Cooper, A Patent Transformation: Woodworking Mechanization in Philadelphia, 1830-1856 at 278, 295315 , in EARLY AMERICAN TECHNOLOGY: MAKING AND DOING THINGS FROM THE COLONIAL ERA TO 1850 (Judith A. McGaw, ed., 1994), which includes illustrations of Woodworth's machine.

49. Patent Act of 1836 , ch. 357, $\S 18,5$ Stat. 117, repealed by Act of July 8, 1870, ch. $230, \S \S 59,111,16$ Stat. 198, 207, 216. In Wilson v. Rousseau, 45 U.S. (4 How.) 646 (1846), a divided Supreme Court had dismissed a challenge to the statutory extension, giving a detailed history of the Woodworth patent and the litigation under it. 
mentioned by name..$^{50}$ Bloomer was a manufacturing licensee under the patent, and McQuewan was a purchaser/user of at least one of the machines. The original patent term had expired during McQuewan's ownership of the machine, and McQuewan had accordingly stopped paying royalties. When the patent was retroactively extended, however, Bloomer demanded that McQuewan pay royalties again for the remaining life of the revived patent. ${ }^{51}$ The question before the Supreme Court was whether the extension of the patent term served to extend the royalty obligation retroactively to buyers, who had purchased the patented product, agreeing to pay royalties for the life of the patent under the shorter term in effect at the time of their purchase.

The case thus implicated concerns similar to those expressed in the Contract Clause of the Constitution - that is, of legislative rewriting of an executed contract so as to make its terms less favorable to one of the parties. ${ }^{52}$ The Contract Clause applies only to the states, however, and patent law is federal. Chief Justice Taney rather creatively attached Contract Clause concerns to the Fifth Amendment Due Process Clause, creating what many people regard as the historical foundation for Substantive Due Process analysis, which developed in the state courts thirty years later:

The right to construct and use these planing machines, had been purchased and paid for without any limitation as to the time for which they were to be used. They were the property of the respondents [i.e., McQuewan, the purchaser of the machine]. Their only value consists in their use. And a special act of Congress, passed afterwards, depriving the appellees of the right to use them, certainly could not be regarded as due process of law.

Congress undoubtedly have power to promote the progress of science and useful arts, by securing for limited times, to authors and inventors, the exclusive right to their respective writings and discoveries.

But it does not follow that Congress may, from time to time, as often as they think proper, authorize an inventor to recall rights which he had granted to others; or reinvest in him rights of property which he had before conveyed for a valuable and fair consideration..$^{53}$

50. An Act to extend a patent heretofore granted to William Woodworth, 6 Stat. 936

51. On the general outcry of users over the retroactive patent extensions, see The Woodworth Patent Extension Scheme, 11 SCI. AM. 277 (1856). See also H.R. REP. No. 31-150 (1850); H.R. REP. No. 32-156 (1852); Petition of Three Hundred Citizens of Wheeling, Virginia, as well as summaries of other petitions, collected in Representative John Otis, Speech of Hon. John Otis, of Maine, and the Minority Report of the Committee on Patents Made by Him, on the Subject of Woodworth's Patent for a Planing Machine, and Against the Bill for Extending that Patent, U.S. House of Reps. (Mar. $27,1850)$, in 89 CONG. \& POLIT. PAMPHLET (1850).

52. U.S. CONST. art. I, $\S 10$, cl. 1 ("No State shall . . pass any ... Law impairing the Obligation of Contracts ....").

53. Bloomer v. McQuewan, 55 U.S. (14 How.) 539, 553 (1852). 
The issue of a legislated retroactive patent term extension subsequent to the sale of a patented product makes Bloomer relatively unique among patent exhaustion cases. Bloomer's rational is also absolutely consistent with the Patent Act's purpose, which is to promote innovation. A retroactive patent term extension cannot incentivize innovation, because the affected technology has already been invented. Assuming that a judge-made patent law rule must fall within the constitutional authorization created in the IP Clause, the Bloomer rationale qualified.

Mitchell $v$. Hawley, decided twenty years later, also applied something akin to the first sale doctrine to hold that the retroactive term extension created in the 1836 Patent Act did not revive the right to an injunction against someone who purchased the patented good under the original term. ${ }^{54}$ No subsequent patent exhaustion case has implicated a retroactive term extension or Congressional modification of an existing license agreement. ${ }^{55}$

The facts of Bloomer thus make it a one-off, forcing later decisions to look for different rationales. Justice Miller's opinion in Adams v. Burke, ${ }^{56}$ the Supreme Court's next major patent exhaustion decision, is notable for both its brevity and its formalism. Further, it is not clear that the decision implicated the first sale doctrine at all. The patentee had licensed various manufacturers to make its coffin lids in designated parts of the country. These licenses to manufacture did not implicate the first sale doctrine because nothing was being sold. Indeed, territorially restricted production licenses are expressly authorized by the Patent Act, at least when they are domestic. ${ }^{57}$ Adams was not a coffin manufacturer but an undertaker. He legally purchased a finished coffin containing the patented lid from a manufacturer who had a territorially restricted license.

The lawsuit was apparently based on the premise that, because the manufacturer was licensed to produce the coffin lids and sell them in a designated area, the purchaser/user implicitly operated under the same limitation. Nevertheless, the sale from the manufacturing licensee to Adams was "without condition or restriction." In contrast to this assumption, the presumptive antitrust rule for territorial restrictions has always been that a restriction on an intermediary does not automatically extend to the end user. For example, an automobile dealer location clause restricts the area in which the

54. Mitchell v. Hawley, 83 U.S. (16 Wall.) 544 (1872).

55. Cf. Eldred v. Ashcroft, 537 U.S. 186 (2003) (upholding a statutory copyright term extension in an action brought by users of copyrighted works which had fallen into the public domain but were revived by the extension). However, it appears that no petitioner alleged that he or she had purchased a work under an ongoing royalty requirement which had lapsed but which the term extension had now revived.

56. Adams v. Burke, 84 U.S. (17 Wall.) 453 (1873).

57. See 35 U.S.C. $\$ 261$ (2018) (granting patentee the right to "grant and convey an exclusive right under his application for patent, or patents, to the whole or any specified part of the United States").

58. See Adams, 84 U.S. at 454-55. The lower court contains somewhat more elaboration but describes the license and sale in the same way. See Adams v. Burks, 1 F. Cas. 100 (C.C.D. Mass. $1871)$. 
dealer can sell a car, ${ }^{59}$ but the clause itself does not serve to restrict the area in which the dealer's customers can drive the car nor whether customers can resell it as a used car. A franchise contract such as one for McDonald's almost certainly includes a location restriction imposed on the franchisee, but no court has ever held that such a clause requires the customer to eat her hamburger inside the store. So one thing missing from Adams was an analysis of the reach-through effect of the territorial restriction-i.e., whether it applied only to the manufacturer or also to someone who subsequently purchased from the manufacturer.

Nevertheless, the premise of Justice Bradley's dissent was the ancient property law principle that one cannot convey a greater title than he owns:

If it be contended that the right of vending the lids to others enables them to confer upon their vendees the right to use the lids thus sold outside of the limited district, the question at once arises, how can they confer upon their vendees a right which they cannot exercise themselves? The only consistent construction to be given to such an assignment is, to limit all the privileges conferred by it to the district marked out. It is an assignment of the manufacture and use of the patented article within that district, and within that district only. ${ }^{60}$

The plaintiff in Adams was a different licensee, whose manufacturing license covered the territory in which Adams buried the coffin in question. ${ }^{61}$ The patentee had assigned exclusive territories to manufacturing licensees, but did so by conveying the entire interest in the patent to each licensee. ${ }^{62}$ Adams, the undertaker, apparently had a license only by virtue of the fact that the purchaser of a patented good always receives an implied license to practice the patent to the extent of using that good. ${ }^{63}$ The patent itself was minor, although perhaps not trivial. Coffins of the day bore a small metal plate stating the decedent's name and other information. Traditionally, the plate was on the lid, however, and could be seen by mourners only when the lid was closed. The patentee cut a notch in the lid between the hinges that permitted the name plate to be viewed when the lid was either open or closed, thus making the plate viewable in open casket funerals. ${ }^{64}$

59. E.g., White Motor Co.v. United States, 372 U.S. 253 (1963) (imposing territorial restriction on a large truck distributor).

60. Adams, 84 U.S. at $458-59$ (Bradley, J., dissenting).

61. See Adams v. Burkes, 1 F. Cas. 100, 100 (C.C.D. Mass. 1871).

62. Adams, 84 U.S. at 458 (noting that the patentees "did assign to Lockhart \& Seelye, of Cambridge, in Middlesex County, Massachusetts, all the right, title, and interest which the said patentees had in the invention described in the said letters-patent, for, to, and in a circle whose radius is ten miles, having the city of Boston as a centre").

63. See supra note 4.

64. U.S. Patent No. 38,713 (issued May 26, 1863), contains an illustration of a coffin bearing the invention. 


\section{B. Distinguishing Unconditional from Conditional Licenses}

The lower court's opinion in Adams, which the Supreme Court affirmed, also contained the language that the Federal Circuit came to rely on in its own exhaustion jurisprudence, ${ }^{65}$ but which the Supreme Court rejected in Impression Products. The Adams Circuit Court held that "[w]hen a patented product passes lawfully into the hands of a purchaser without condition or restriction, it is no longer within the monopoly or under the protection of the patent act, but outside of it." ${ }^{\prime 66}$ In subsequent decisions, the Supreme Court characterized the Adams decision in that way and expressly followed its reasoning. ${ }^{67}$

After Adams, courts justified patent exhaustion with several different, sometimes overlapping rationales. Commentators have also inferred rationales that were not often expressed in judicial decisions, although they may have been implied. One rationale was based on the distinction between conditional and unconditional sales that Adams, Henry, and numerous other decisions stated. A second was a concern that the law of patented things (as opposed to the law of patents) needed to be reserved to the extent possible to other bodies of law, such as commercial law-or more pointedly, to the states. ${ }^{68} \mathrm{~A}$ third rationale, articulated frequently after the Clayton Act was passed, was that the first sale doctrine served to limit anticompetitive vertical agreements, and thus pulled in tandem with both the antitrust laws and the developing patent "misuse" doctrine. ${ }^{69}$ Finally, concerns about outlawing restraints on the alienation of chattels were acknowledged, but only infrequently. The concern with restraints on alienation was articulated more often in copyright law as well as the developing antitrust law of vertical restraints. In the latter, it formed the rationale for the set of per se rules against vertical restrictions that the Supreme Court initially developed but later largely rejected. ${ }^{70}$

Historically, the most frequently stated rationale for the first sale doctrine was a version of the one that the Federal Circuit was following at the time of Impression Products, which distinguished unconditional from conditional sales

65. See supra notes 56-59 and accompanying text.

66. Adams v. Burks, 1 Holmes 40, 1 F.Cas. 100, 100 (C.C.D.Ma. 1871).

67. Hobbie v. Jennison, 149 U.S. 355, 362 (1893) ("[I]n Adams v. Burke it was assumed that the patented coffin lids were first lawfully sold to the purchaser, without condition or restriction."); accord Mitchell v. Hawley, 83 U.S. (16 Wall.) 544, 547 (1872) ("[A] patentee, when he has himself constructed a machine and sold it without any conditions, or authorized another to construct, sell, and deliver it, or to construct and use and operate it, without any conditions, and the consideration has been paid to him for the thing patented, the rule is well established that the patentee must be understood to have parted to that extent with all his exclusive right, and that he ceases to have any interest whatever in the patented machine."); Keeler v. Standard Folding Bed Co., 157 U.S. 659, 663 (1895) (quoting Mitchell on this point); see also Motion Picture Patents Co. v. Universal Film Mfg. Co., 243 U.S. 502, 516 (1917) (holding that the Patent Act's exclusive right to vend "is exhausted by a single, unconditional sale, the article sold being thereby carried outside the monopoly of the patent law ....").

68. See infra notes 79-94 and accompanying discussion.

69. See infra notes 95-108 and accompanying discussion.

70. See infra notes 128-134 and accompanying discussion. 
of patented things. Once a patentee had made an unconditional sale of a patented thing, then any use restriction imposed on the purchaser was unenforceable. On the other hand, conditional sales should be enforced when the limiting condition was clear and simultaneous with (or announced prior to) the sale.

The common law had always recognized that property owners could transfer something less than their "entire" interest in property, and patents were no exception. Speaking for the Supreme Court, Justice Peckham observed this in the 1902 Bement Harrow case, which upheld patent cross-licenses issued on the condition that the parties set a specific price for their patented harrows. ${ }^{71}$ The "general rule is absolute freedom in the use or sale of rights under the patent laws." $" 72$ He wrote:

The very object of these laws is monopoly, and the rule is, with few exceptions, that any conditions which are not in their very nature illegal with regard to this kind of property, imposed by the patentee and agreed to by the licensee for the right to manufacture or use or sell the article, will be upheld by the courts. The fact that the conditions in the contracts keep up the monopoly or fix prices does not render them illegal. ${ }^{73}$

The distinction between conditional and unconditional sales effectively turns the patent exhaustion rule into a drafting problem, at least to the extent that the particular condition does not violate antitrust law or some other legal policy. As the Federal Circuit articulated it in its now-overruled Mallinckrodt decision, the "principle of exhaustion of the patent right did not turn a conditional sale into an unconditional one."74 The court then noted numerous Supreme Court decisions that had rested exhaustion on the distinction between conditional and unconditional sales ${ }^{75}$ and concluded that:

Adams v. Burke and its kindred cases do not stand for the proposition that no restriction or condition may be placed upon the sale of a patented article .... Unless the condition violates some other law or policy (in the patent field, notably the misuse or antitrust law), private parties retain the freedom to contract concerning conditions of sale. ${ }^{76}$

As Mallinckrodt read the twentieth-century case law, the decisions refusing to enforce a post-sale restriction even when a clear condition had been stated did

\begin{aligned} & \hline 71. Bement v. Nat'l Harrow Co., 186 U.S. 70 (1902). \\ & 72. Id. at 91. \\ & 73. Id. \\ & 74. Mallinckrodt, Inc. v. Medipart, Inc., 976 F.2d 700, 706 (Fed. Cir. 1992), abrogated \\ & by Impression Prods., Inc. v Lexmark Int'l, Inc., 137 S. Ct. 1523 (2017). \\ & 75. Id. at 706-07. \\ & 76. Id. at 708 (citation omitted). \end{aligned}


not rest on the first sale doctrine at all, but rather on the conclusion that the particular condition being asserted amounted to misuse or an antitrust violation. ${ }^{77}$

\section{Trading Off Duration and Enforcement Scope}

When a practice such as tying, exclusive dealing, resale price maintenance, or something else is found unlawful under the antitrust laws, it is typically condemned no matter whether it is enforceable by contract or infringement action. But does a class of restraints exist that, while enforceable by breach of contract action, should not be enforceable by infringement suit? On the one hand, the duration of a restraint enforced by contract is as long as the contract is enforceable, perhaps indefinitely. That is also true of trademarks and trade secrets, whose duration is indefinite. By contrast, a restraint enforceable by a patent infringement action can last no longer than the enforceable life of the patent. So if the duration of the restraint is an important factor, the patent infringement suit has the advantage. ${ }^{78}$

On the other hand, because infringement actions do not require privity of contract, they can reach a broader set of potential defendants. However, that is not a bad thing, unless enforcement itself is socially harmful. As noted earlier, if the restraint at issue is welfare increasing, then enforcement via infringement actions is preferable to no enforcement at all. The current law of exhaustion does not make any of these distinctions. Once a qualifying sale occurs, the post-sale restraint is unenforceable, no matter what its consequences for welfare, competition, or innovation.

\section{Preserving Room for the Law of Patented Things-Concerns for Federalism}

Duffy and Hynes argue that the central purpose of the exhaustion doctrine is to preserve space for other areas of law, such as commercial law. ${ }^{79}$ Under this rationale, the Patent Act creates a regime for controlling patents, but other bodies

77. Patent "misuse" is another judge-made set of rules that refuse to enforce patents that have been "misused," most typically by tying or some related practice. On patent misuse and its relation to antitrust, see 10 Phillip E. AREeda \& Herbert HovenKamp, ANTITRust LAW $91782 \cdot$ (4th ed. forthcoming 2018).

78. Then-Sixth Circuit Judge Lurton made this point in his opinion in the Dr. Miles resale price maintenance case which the Supreme Court subsequently affirmed. RPM enforced through IP licensing, he observed, "has a limitation of a few years" and requires the inventor to put his invention on record. Dr. Miles Med. Co. v. John D. Park \& Sons Co., 164 F. 803, 806 (6th Cir. 1908), aff'd, 220 U.S. 373 (1911). By contrast, speaking of a price restraint enforceable by a contract action:

Not so with the monopoly asked for by those who control the enormous proprietary trade of this

country. Their monopoly will go on forever, and, if there be merit in their formula, they may not only preserve it through all time, but continue to restrain prices and prevent competition in the sale of the product. It is said that the proprietor of such a secret remedy need never communicate his formula. Id.

79. John F. Duffy \& Richard Hynes, Statutory Domain and the Commercial Law of Intellectual Property, 102 VA. L. REV. 1 (2016). 
of law control the use, sale, and deployment of patented things. For example, an insecticide might be patented, with composition and right to manufacture controlled by the Patent Act. Nevertheless, numerous other bodies of law govern the use, production, and sale of the insecticide itself-the enforceability of sales contracts and remedies for breach, the conditions under which it may be manufactured, whether and when it can be used or even whether it can be used at all, ${ }^{80}$ how it is to be sold, anticompetitive restraints on its sale, or how it must be labeled.

This is an intuitively appealing rationale for patent exhaustion. It is not a rationale that the courts have often articulated, however - at least not in the form that Duffy and Hynes describe it. Another problem is that it creates a kind of ratchet. Patent exhaustion makes room for alternative bodies of law when they are more restrictive. It does so less well when they are more permissive. For example, exhaustion accommodated the concerns of antitrust quite well when antitrust was on an expansion course, making per se unenforceable what antitrust was also making per se unlawful. The two most important categories were tying arrangements and resale price maintenance, which were two of the practices most frequently involved in first sale situations. Both were historically unlawful per se. However, when antitrust changed course and began to see these practices as more benign or even as economically efficient, the first sale doctrine went right on denying enforcement, as it did in the Impression Products case. As noted earlier, to the extent that the variable proportion print/cartridge tie at issue in Impression Products is socially efficient and cannot effectively be enforced by a breach of contract suit, the first sale doctrine serves to frustrate rather than support antitrust goals.

I have proposed a variation, which I believe is more faithful to the historical development of the patent exhaustion doctrine. Further, it was widely cited by the courts as the rationale. The purpose of the exhaustion doctrine was to preserve the boundary between the federal law of patents and the largely state law of patented things. ${ }^{81}$ During the nineteenth century patent law increasingly became federal, although the Supreme Court would not get around to preempting state issued patents until the $1960 \mathrm{~s}^{82}$ A frequently articulated rationale for patent exhaustion during that time was that the doctrine served to distinguish between the federal law of patents, as covered by the Patent Act and IP Clause of the Constitution, from state law governing the sale and use of patented objects. The

80. See, e.g., Patterson v. Kentucky, 97 U.S. 501 (1878) (holding that the fact that a fuel oil was patented did not defend against state statute prohibiting its use as unsafe); see also Webber v. Virginia, 103 U.S. 344, 347 (1880) ("The patent for a dynamite powder does not prevent the State from prescribing the conditions of its manufacture, storage, and sale, so as to protect the community from the danger of explosion. A patent for the manufacture and sale of a deadly poison does not lessen the right of the State to control its handling and use.").

81. Hovenkamp, supra note 8.

82. Compco Corp. v. Day-Brite Lighting, 376 U.S. 234 (1964); Sears, Roebuck \& Co. v. Stiffel Co., 376 U.S. 225 (1964). On the history of federal exclusivity, see Herbert Hovenkamp, The Emergence of Classical Patent Law, 58 ARIZ. L. REV. 263 (2016). 
Tenth Amendment guarantees that powers not delegated to Congress under the IP Clause or potentially overlapping provisions such as the Commerce Clause should be reserved to the states. ${ }^{83}$

Chief Justice White articulated this position very forcefully in his dissent from the Supreme Court's Henry decision, which approved a variable proportion patent tie accomplished by a conditional sale. ${ }^{84}$ Speaking of the majority's holding that the Patent Act entitled the patentee to enforce its tie via an infringement action, White complained that the effect was

\begin{abstract}
to destroy, in a very large measure, the judicial authority of the states by unwarrantedly extending the Federal judicial power .... [T] he gravity of the consequences which would ordinarily arise from such a result is greatly aggravated by the ruling now made, since that ruling not only vastly extends the Federal judicial power, as above stated, but as to all the innumerable subjects to which the ruling may be made to apply, makes it the duty of the courts of the United States to test the rights and obligations of the parties, not by the general law of the land, in accord with the conformity act, but by the provisions of the patent law, even although the subjects considered may not be within the embrace of that law, thus disregarding the state law, overthrowing, it may be, the settled public policy of the State, and injuriously affecting a multitude of persons. ${ }^{85}$
\end{abstract}

As the Chief Justice realized, because a condition in a patent license could be drafted to cover everything a contract could cover, the impact of not finding exhaustion would be to federalize state commercial law, state competition law, or any other body of state law having to do with the use or sale of patented things. As Henry was being written in 1912, state antitrust laws were just starting to deal with practices such as resale price maintenance and tying. ${ }^{86}$ Federal law had already condemned resale price maintenance, ${ }^{87}$ but there was as yet no federal antitrust law of tying. The Henry ruling permitting A.B. Dick to enforce its tying restriction effectively preempted any state law attempt to condemn such ties. That is why Congress responded two years later by making anticompetitive ties subject to federal law. ${ }^{88}$ In sum, the logic of Henry enabled federal infringement law to ride roughshod over state law.

Chief Justice White was hardly the first to see patent exhaustion in terms of federalism. In fact, his dissent reflected a view stated in several court opinions

83. U.S. CONST. amend. X.

84. Henry v. A.B. Dick \& Co., 224-U.S. 1 (1912).

85. Id. at 49-50 (White, C.J., dissenting).

86. See Butterick Pub. Co. v. Fisher, 89 N.E. 189 (Mass. 1909) (applying state antitrust law to exclusive dealing); In re Op. of the Justices, 81 N.E. 142, 145 (Mass. 1907) (concluding that a state law condemning patent ties would be constitutional if passed); Commonwealth v. Strauss, 78 N.E. 136 (Mass. 1906) (applying state antitrust law to exclusive dealing); Tex. Brewing Co. v. Meyer, 38 S.W. 263 (Tex. 1896) (holding similar); see also Brown v. Jacobs Pharmacy Co., 41 S.E. 553, 559 (Ga. 1902) (condemning resale price maintenance under state antitrust law); Klingel's Pharmacy v. Sharp \& Dohme, 64 A. $1029,1029-30$ (Md. 1906) (holding the same).

87. Dr. Miles Medical Co. v. John D. Park \& Sons Co., 220 U.S. 373, 405 (1911).

88. Clayton Act $\S 3,15$ U.S.C. $\S 14$ (2012). 
that stretched back to the mid-nineteenth century. That view, quite simply, was that when a device was sold it passed from the patent law written by Congress to the domain of state common and statutory law governing the sale and use of goods. This was an essential mechanism for identifying the boundary between the power granted by the IP clause of the Constitution to the federal government and state power to control commerce in everything that federal law did not embrace.

In 1859 , the Supreme Court defined patent exhaustion, stating that "[b]y a valid sale and purchase, the patented machine becomes the private individual property of the purchaser, and is no longer protected by the laws of the United States, but by the laws of the State in which it is situated." 89 The Supreme Court and lower courts repeated that formulation many times in patent exhaustion cases during the latter half of the nineteenth century and first quarter of the twentieth century. ${ }^{90}$ It was used at least twice by the Supreme Court in variable proportion patent tying cases similar to Henry and Impression Products and several additional times by lower federal courts. ${ }^{91}$ In all of these cases, the courts cited these concerns for federalism, virtually always quoting the language from Chaffee.

As in so many areas, these concerns for federalism disappeared during the Progressive Era and the New Deal. ${ }^{92}$ Federal authority over patented things expanded, most notably under the antitrust laws, but also later under the expansion of federal Commerce Clause power recognized in Wickard $v$. Filburn. ${ }^{93}$ Beginning with the Motion Picture case in 1917, the Court increasingly saw the exhaustion doctrine as a complement, not so much to state commercial law, but rather to federal antitrust law. ${ }^{94}$

\section{E. Competition Concerns Rationalizing Exhaustion}

In Henry, the Court rejected the defendant's argument that the Sherman Act had anything to say about the variable proportion patent tie at issue in that case. Congress passed the Clayton Act two years later, however, mentioning patents for the first time in an antitrust law. In its first subsequent exhaustion case, Motion Picture Patents, the Supreme Court found linkage and rejected the

89. Chaffee v. Bos. Belting Co., 63 U.S. (22 How.) 217, 223 (1859).

90. The decisions are collected in Hovenkamp, supra note 81 .

91. Morgan Envelope Co. v. Albany Perforated Wrapping Paper Co., 152 U.S. 425 (1894) (holding that exhaustion applied to a tie of patented toilet paper dispenser to toilet paper); Wilson v. Simpson, 50 U.S. 109 (1850) (holding that a purchaser of Woodworth planning machine had right to replace worn out blades with those of his own making); Wagner Typewriter Co. v. F.S. Webster Co., 144 F. 405 (C.C.S.D.N.Y. 1906) (holding the same for a tie of typewriter to typewriter ribbons); Aiken $v$. Manchester Print Works, 1 F. Cas. 245, 246-247 (C.C.D.N.H. 1865) (holding the same for a tie of patented knitting machine to disposable knitting needles).

92. On this point, see HERBERT HOVENKAMP, THE OPENING OF AMERICAN LAW NEOCLASSICAL LEGAL THOUGHT, 1870-1970, at 290-292 (2015).

93. 317 U.S. 111 (1942).

94. Motion Picture Patents Co. v. Universal Film Mfg. Co., 243 U.S. 502 (1917), 
"condition" distinction. ${ }^{95}$ The Clayton Act served to "confirm" the Court's view that the patent tie requiring users of the patentee's projector to show only its films was both unenforceable under the exhaustion rule and an antitrust violation. ${ }^{96}$ Justice Holmes dissented, making clear that he would have preserved the distinction between conditional and unconditional sales. ${ }^{97}$

For some time thereafter, antitrust policy and the first sale doctrine pulled in tandem, culminating in the Univis Lens decision in $1942 .{ }^{98}$ After that, the Supreme Court abandoned patent exhaustion jurisprudence for sixty-five years. ${ }^{99}$ Univis sold patentẹ, unground lens blanks for making bifocal eyeglasses, together with a license for a process patent for grinding them. The sales agreement required resellers of the finished lenses to sell them at a stipulated minimum price. The Court held that the condition was unenforceable under the first sale doctrine, but also that it violated the Sherman Act. While the Court cited the principal patent exhaustion cases, it followed the Motion Picture case and omitted the distinction between conditional and unconditional sales. The Court's 2008 Quanta Computer decision was insufficiently clear about the condition requirement, ${ }^{100}$ but Impression Products categorically rejected it. ${ }^{101}$ In his opinion for the Court in Kirtsaeng, Justice Breyer also expressly tied copyright exhaustion policy to antitrust policy. ${ }^{102}$

One feature of the antitrust rationale for exhaustion is that it does not treat the "sale" of the patented good as important. That is, if antitrust doctrine applies at all, it applies to both contract enforcement and to conditions attached to the sale of patented goods. Section 3 of the Clayton Act makes this clear with its use of "condition or understanding" as the relevant term signifying agreement. Further, the Clayton Act expressly references leases as well as sales. ${ }^{103}$ Beginning with Motion Picture Patents, Section 3 of the Clayton Act has been

projector sold.

95. Id. at 514. As in Henry, the condition was clearly stated in a notice affixed to each

96. Id. at 517 ("We are confirmed in the conclusion which we are announcing by the fact that since the decision of Henry v. A. B. Dick Co. supra, the Congress of the United States, the source of all rights under patents, as if in response to this decision, has enacted a law making it unlawful for any person engaged in interstate commerce "to lease or make a sale ...." (citing Clayton Act $\$ 3,15$ U.S.C. $\S 14(2018))$.

97. Id. at 519-20 ("Generally speaking, the measure of a condition is the consequence of a breach, and if that consequence is one that the owner may impose unconditionally, he may impose it conditionally upon a certain event.").

98. United States v. Univis Lens Co., Inc., 316 U.S. 241 (1942). Inc., 553 U.S. 617 (2008).

99. The next Supreme Court decision was Quanta Computer, Inc. v. LG Electronics,

100. Id. at 637 .

101. See Impression Prods., Inc. v. Lexmark Int'l., Inc., 137 S. Ct. 1523 (2017) ("We conclude that a patentee's decision to sell a product exhausts all of its patent rights in that item, regardless of any restrictions the patentee purports to impose or the location of the sale.").

102. Kirtsaeng v. John Wiley \& Sons, Inc., 568 U.S. 519 (2013) (linking the policy against restraints on alienation to antitrust policy).

103. See 15 U.S.C. $\S 14$ (2018) ("It shall be unlawful ... to lease or make a sale or contract for ... on the condition, agreement, or understanding that the lessee or purchaser thereof shall not use or deal in the goods ... of a competitor ...."). 
applied to both patented and unpatented goods and to both leases and sales. ${ }^{104}$ The only limitation on domain is that the sale be one of "goods" or "commodities." That is, the provision does not apply to services. ${ }^{105}$

Of course, if patent exhaustion applied only to restraints that violated the antitrust laws anyway, then there would be little independent need for an exhaustion doctrine. The antitrust laws would already be doing by statute what the patent exhaustion rule was intended to do. In any event, this is not the law under Impression Products. That decision refused to enforce a variable proportion tying restriction that antitrust law today would almost certainly approve, particularly given the lack of any evidence that Lexmark possessed market power. The Patent Act itself requires market power to make a patent tie unlawful. ${ }^{106}$ By contrast, exhaustion applies to any post-sale restraint, even one with no anticompetitive or anti-innovation consequences whatsoever.

Also worth noting is that turning practices such as patent ties into antitrust violations considerably broadens enforcement, enabling the government or private plaintiffs to challenge the practices directly rather than wait for a patent infringement suit. Prior to Univis, patent exhaustion appeared only as a defense to an infringement or contributory infringement action. There was no private right to sue a patentee for violating the exhaustion rule. A declaratory judgment action might possibly have worked, ${ }^{107}$ but the federal statute authorizing them was not passed until $1934 .{ }^{108}$ By contrast, Univis was an antitrust enforcement action brought by the United States to restrain enforcement of the post-sale condition in question as unlawful resale price maintenance. Even if the Court had not applied exhaustion the defendant would have lost on antitrust grounds.

\section{F. Policing Restraints on Alienation}

The Impression Products decision drew its rationale for exhaustion almost exclusively from the common law's hostility toward restraints on alienation. Chief Justice Roberts relied on two common law sources. One was Lord Coke's

104. E.g., IBM v. United States, 298 U.S. 131 (1936) (applying Section 3 of the Clayton Act to a defendant who leased its computing machines and required lessee to purchase paper data cards from itself); United Shoe Mach. Corp. v. United States, 258 U.S. 451 (1922) (applying Section 3 of Clayton Act to tying clauses in leases of shoe machinery).

105. See 15 U.S.C. $\$ 14$ (2018) (referring to "goods, wares, merchandise, machinery, supplies, or other commodities, whether patented or unpatented").

106. 35 U.S.C. $\$ 271$ (d) ("No patent owner ... shall be denied relief or deemed guilty of misuse or illegal extension of the patent right by reason of his having . . . conditioned the license of any rights to the patent or the sale of the patented product on the acquisition of a license to rights in another patent or purchase of a separate product, unless, in view of the circumstances, the patent owner has market power in the relevant market for the patent or patented product on which the license or sale is conditioned."); see also discussion accompanying infra notes 158-163 (arguing that this provision limits exhaustion).

107. But see Cont'l Auto. GmbH v. iBiquity Dig. Corp., 14-c-1799, 2015 WL 859569 (N.D. Ill. Feb. 26, 2015) (holding that a declaratory judgment action cannot be brought against a practice that does not arise under federal law, but that is asserted only as a defense).

108. 28 U.S.C. $\$ \S 2201-02$ (2018). 
early seventeenth century treatise, Institutes of the Lawes of England. ${ }^{109}$ The other was the writings of John Chipman Gray, a Harvard Professor, close friend of Holmes, and eminent authority on common law restraints on alienation.

Gray had actually written two important legal treatises dealing with restraints on property: Restraints on the Alienation of Property ${ }^{110}$ and The Rule Against Perpetuities. ${ }^{111}$ The fact that he wrote two rather large books on the subject suggests that the legal rules governing restraints on alienation were significantly more nuanced than Impression Products and other patent exhaustion decisions describe them. In fact, there was no simple rule that all restraints on alienation, even on personal property, were unenforceable. Rather, the legal status of the restraint depended on a number of things, such as the type of property, whether real or personal; the nature of the interest being conveyed, whether vested or contingent; the length of the term of the underlying conveyance; the nature of the restraint; and the duration of the restraint itself. Further, only a subset of restraints were on "alienation" as such, although many more might affect market value.

For example, Gray's Restraints on Alienation includes a section on restraints that were "Qualified as to Time," 112 indicating that many time-limited restraints were approved. This is important because patent law's exhaustion doctrine applies to enforcement via patent infringement actions, which ordinarily can be maintained only against conduct that occurs during the enforcement life of the patent. So by definition, the time limit is fairly short-less than twenty years in the typical case, and certainly short by the standards of the common law. As Gray famously stated it, the common law rule against perpetuities was that "no interest is good unless it must vest, if at all, not later than twenty-one years after some life in being at the creation of the interest." 13 A skilled drafter could tie up property for a century or more under the rule. ${ }^{114}$ Gray suggested a shorter rule for express restraints on alienation, which is that the condition, "if broken at all must have been broken in the lifetime of the first taker." ${ }^{115} \mathrm{He}$ also discussed several cases, however, approving restraints that lasted into the second generation. ${ }^{116}$ With respect to U.S. law, Gray found a great deal of controversy

\footnotetext{
109. 1 EDWARD COKE, INSTITUTES OF THE LAWES OF ENGLAND $\S 360$, at 223 (1628).

1895).

110. JOHN CHIPMAN GRAY, RESTRAINTS ON THE ALIENATION OF PROPERTY (2d ed.

111. John Chipman Gray, The RULe AGainst Perpetuities (1886).

112. GRAY, supra note $110, \S \S 45$, at 33 .

113. GRAY, supra note $111, \S 201$.

114. For example, a grant that kept an interest in the family "until twenty years
} following the death of the survivor of my three grandchildren, Peter, Paul, and Mary" would restrain alienation until twenty years after the last of these three grandchildren died. If Mary, the survivor, was three at the time the interest was created and lived to be 93 , the interest would have been tied up for $90+$ 20 , or 110 years.

115. Gray, supra note $110, \S 47$, at 34 .

116. E.g., id. (citing Pearson v. Dolman, L.R., 3 Eq. 315 (1866) (Eng.) (upholding a restraint on alienation of a fund for which alienation was restrained until the grantee turned twenty-five, even though the grantee died prior to his twenty-fifth birthday)). 
over the legal effect of restraints "confined to a limited period," with a majority stating that they were good. ${ }^{117}$ Gray himself believed that a more restrictive rule was better. ${ }^{18}$

This is not the place to rehearse the common law of restraints on alienation of property. Clearly, however, a blanket rule that any sale of a patented article forecloses subsequent enforcement of a restraint shorter than twenty years is an egregious exaggeration of the common law's position. ${ }^{119}$ Further, only a small subset of the restraints to which patent exhaustion has been applied are properly classified as restraints on "alienation." Most of them are more properly described as use limitations, governing such things. as limitations to a single use, ${ }^{120}$ limitations on the types of components with which the restrained product may be used, ${ }^{121}$ or territorial limitations on where a product can be used. ${ }^{122}$ The particular restriction that comes closest to a restraint on alienation is resale price maintenance clauses, which specify the minimum price at which a restrained good can be resold. ${ }^{123}$ Even these, however, are not prohibitions on alienation, but rather limitations on the price of alienation. ${ }^{124}$ Indeed, resale price maintenance is imposed only on resellers, thus contemplating that the product is going to be resold.

Applying Gray's concern about alienation restraints also takes the common law's concern completely out of its established context. The common law doctrine was addressed to issues concerning the preservation of family wealth. Nothing in Gray suggests application to either intellectual property transfers or, more generally, to restraints governing commercial distribution. Restraints such as those in Impression Products or the other antitrust and patent cases where the doctrine has been cited arise in the context of distribution schemes that contemplate that the good will be resold. Their purpose is not to restrain alienation in the common law sense at all, but only to channel or direct the way that a good is distributed. Further, we apply antitrust's rule of reason to such restraints because we believe that most of them serve to increase rather than

117. GRAY, supra note 110 , at $\S \S 52-53$.

118. Id. at $\S 54$.

119. The copyright rule may be more justifiable, given the Copyright Act's current duration of life of the author plus seventy years for most sole-authored works. 17 U.S.C. $\$ 302(2018)$.

120. Impression Prods., Inc. v. Lexmark Int'l., Inc., 137 S. Ct. 1523 (2017) (striking down a prohibition on refilling empty toner cartridge); Am. Cotton-Tie Co. v. Simmons, 106 U.S. 89 (1882) (upholding a similar provision); Mallinckrodt, Inc. v. Medipart, Inc., 976 F.2d 700 (Fed. Cir. 1991) (upholding a single use limitation).

121. Quanta Computer, Inc. v. LG Elec., Inc., 553 U.S. 617 (2008) (striking down a restraint limiting use of device with competitors' components).

122. Adams v. Burke, 84 U.S. 453 (1873) (striking down a territorial limitation).

123. E.g., United States v. Univis Lens Co., Inc., 316 U.S. 241 (1942) (striking down a resale price maintenance clause); Bobbs-Merrill Co. v. Straus, 210 U.S. 339 (1908) (holding the same in the copyright context).

124. Gray's own position on price restraints was more benign. See GRAY, supra note $110, \S 81$ (observing cases that upheld restraints that required rights of first refusal to specified buyers willing to match the price). 
decrease sales volume. A restraint reasonably intended to increase sales cannot seriously be called a restraint on alienation. ${ }^{125}$

In sum, Impression Products, Kirtsaeng, and other cases that have adopted a restraint on alienation approach to exhaustion are not following anything resembling the common law on the subject. Rather, they are fashioning a much more draconian federal common law governing post-sale restraints on patented articles, categorically barring them.

Fashioning a new federal common law of restraints on alienation is not what Impression Products and Kirtsaeng purport to be doing, however. Rather, Impression Products defined the exhaustion rule as "mark[ing] the point where patent rights yield to the common law principle against restraints on alienation." $" 126$ Kirtsaeng did very much the same thing, citing the exhaustion rule as "a common-law doctrine with an impeccable historic pedigree."127

Using the common law of restraints on alienation to justify the draconian Impression Products rule also flies in the face of more than a century of development in the antitrust law of restricted distribution. Antitrust courts historically cited a policy against restraints on alienation to justify harsh, per se rules condemning vertical practices such as resale price maintenance and vertical nonprice restraints. For example, the $1911 \mathrm{Dr}$. Miles decision cited the same two sources as Impression Products, Coke and Gray, identifying a policy against restraints on alienation as justifying the now overruled per se rule against resale price maintenance. ${ }^{128}$ In its Leegin decision overruling Dr. Miles, the Court briefly traced out the changing attitudes toward restricted distribution that had made the Dr. Miles rationale obsolete. ${ }^{129}$

In its quickly overruled Schwinn decision, the Court also stated a policy against restraints on alienation as justifying a per se rule against vertical territorial restraints. ${ }^{130}$ That concern was necessary in order to prevent "open[ing] the door to exclusivity of outlets and limitation of territory."131 In his dissent Justice Stewart accused the Court of embracing a common law rule "merely on grounds of its antiquity." "32 There is much to be said for Stewart's observation. The majority's concern reflected a classical regime in which relatively small producers were seen as placing goods on the market unrestricted,

125. See Hovenkamp, supra note 18.

126. Impression Prods., 137 S. Ct. at 1531.

127. See, e.g., Kirtsaeng, 133 S. Ct. at 1363.

128. Dr. Miles Medical Co. v. John D. Park \& Sons Co., 220 U.S. 373, 405 (1911), overruled by Leegin Creative Prods., Inc. v. PSKS, Inc., 55 I U.S. 877 (2007).

129. Leegin, 551 U.S. at 889-90.

130. United States v. Arnold, Schwinn \& Co., 388 U.S. 365 (1967), overruled by Cont'I T.V., Inc. v. GTE Sylvania, Inc., 433 U.S. 36 (1977).

131. Schwinn, 388 U.S. at 380 ("But to allow this freedom where the manufacturer has parted with dominion over the goods-the usual marketing situation-would violate the ancient rule against restraints on alienation and open the door to exclusivity of outlets and limitation of territory further than prudence permits.").

132. Id. at 391 (Stewart, J., dissenting). 
and these then passed anonymously from hand to hand until they ended up with consumers. Modern distribution systems that involve complex products, dedicated aftermarket parts, warranty and ongoing customer service, and brand specificity and trademark licensing were simply not a part of that picture. As Stewart complained:

Centuries ago, it could perhaps be assumed that a manufacturer had no legitimate interest in what happened to his products once he had sold them to a middleman and they had started their way down the channel of distribution. But this assumption no longer holds true in a day of sophisticated marketing policies, mass advertising, and vertically integrated manufacturer-distributors .... [T] he state of the common law 400 or even 100 years ago is irrelevant to the issue before us: the effect of the antitrust laws upon vertical distributional restraints in the American economy today. ${ }^{133}$

When the Supreme Court reversed itself a decade later, placing vertical nonprice restraints under the rule of reason, it disclaimed the Schwinn Court's reliance on a policy against restraints on alienation as "both a misreading of legal history and a perversion of antitrust analysis."134

No good reason exists why the appropriate rule for patent policy should be any different from the rule for antitrust policy. Indeed, one phenomenon that has accompanied the rise of restricted distribution systems is the significantly increased use of all types of intellectual property rights, both to protect innovation and to create product differentiation. It should not be the purpose of exhaustion doctrine to interfere with efficient distribution unless there are compelling, offsetting reasons. All the more, given that the exhaustion rule is entirely judge made.

\section{III.Implications and Reach}

The per se exhaustion rule declared in Impression Products is a poor fit for an economy in which restricted distribution has become the norm, at least for branded, manufactured goods. To be sure, most distribution restraints can be and are enforced by contract law. As Impression Products itself reveals, however, some situations are exceptional. To the extent contract enforcement is inadequate to achieve distribution efficiency, the Impression Products rule may operate so as to make some types of socially useful distribution unworkable. On the other side, there are some circumstances in which enforcement actions against those not in privity of contract are undesirable. This makes exhaustion a good candidate for something resembling "rule of reason" treatment. The hard part, of course, is identifying those factors that favor enforcement from those that disfavor it.

133. Id. at 392 .

134. Cont'l T.V., Inc. v. GTE Sylvania, Inc., 433 U.S. 36, 53 n.21 (1977) 
This section briefly examines some areas that might be affected by the Impression Product decision, and one possible means of evading it, at least for tying arrangements.

\section{A. Standard-Essential Patents (SEPs)-Reversal of Incentives}

Most patentees want their patents to be construed as broadly as possible consistent with maintaining patent validity, for this will broaden the infringement net. ${ }^{135}$ The hard exhaustion doctrine expressed in Impression Products may change this in certain cases, however. A patentee may have an incentive to argue that its patent does not read on a particular product that it sells in order to avoid exhaustion. That effect has already shown up in the ongoing litigation between Apple and Qualcomm. ${ }^{136}$

Suppose that a microchip maker sells a chip to a buyer and also owns a patent that reads on that chip. The chip purchaser then receives an implied license to practice this patent to the extent it uses the chip for its ordinarily intended purpose, which almost certainly includes installation in a device together with other technology. If the patentee attaches a patent notice to the chip tying complementary products or limiting the components with which the chip can be used, Impression Products would prevent that restriction from being enforced by means of a patent infringement suit. ${ }^{137}$

Suppose, however, that the patent does not read on the chip at all, but that the chip purchaser later uses the chip in combination with other technology or processes that might infringe that patent. Exhaustion does not apply, because no relevant patented article has been sold. Further, the patentee might refuse to license the patent unless the licensee takes certain tied products or observes an exclusive dealing restriction. Those provisions would be subject to antitrust scrutiny, but the challenger would have to show that they are anticompetitive. Patent infringement would also be possible if the patentee could establish that the way in which the chip was used infringes its patent, but the sale of the chip itself would not exhaust it. In sum, the patentee may be considerably better off if its patent does not read on the chip in question. ${ }^{138}$

The Supreme Court has addressed such situations, generally ignoring the exhaustion doctrine because it was undisputed that the patent did not read on the

135. While a broad claim construction casts a wider infringement net, it can also lead to a finding of invalidity if it brings in obvious subject matter or the broader claim is not adequately enabled. See, e.g., MagSil Corp. v Hitachi Global Storage Tech., Inc., 687 F.3d 1377 (Fed. Cir. 2012).

136. See Redacted First Amended Complaint, Apple, Inc. v. Qualcomm, Inc., No. 17cv-0108-GPC, 2017 WL 5176922 (S.D. Cal. 2017) [hereinafter Qualcomm Complaint]; see also Qualcomm, Inc. v. Apple, Inc., No. 3:17-cv-01010-GPC, 2017 WL 3966944 (S.D. Cal. Sep. 7, 2017) (order denying Qualcomm's motion for a preliminary injunction compelling payment of royalties).

137. While Impression Products concerned tying, Quanta Computer, Inc. v. LG Electronics, Inc., 553 U.S. 617 (2008), involved restraints on the components with which the patented product could be used.

138. See Erik Hovenkamp, Tying, Exclusivity, and Standard-Essential Patents, 19 COLUM. SCI. \& TECH. L. REV. 79 (2017). 
complementary good. In Leitch, the patentee sold an unpatented asphalt emulsion for use in building roads, together with a patented process for applying it. It claimed that the compound was not commercially viable without the patented process and brought suit against someone who sold the emulsion. Justice Brandeis's decision for the Supreme Court refused to enforce the restriction, concluding that it was an attempt by a patentee of the process to extend it to cover the unpatentable emulsion. ${ }^{139}$

Responding to such decisions, Congress added $\S 271(\mathrm{c})$ to the 1952 Patent Act. That provision stated that someone who sells a "material or apparatus for use in practicing a patented process" can be guilty of contributory infringement if the seller knew that patent infringement was intended and if the material or apparatus is "not a staple article or commodity of commerce suitable for substantial noninfringing use." 140 In Dawson Chemical, the Supreme Court then held that someone who sold an unpatented herbicide and also owned a patent on the only known means of application could lawfully bring an action for contributory infringement against a seller who knew that the purchaser would apply it by infringing the application patent. ${ }^{141}$ The Court did not discuss patent exhaustion because no sale of a patented product was in issue. ${ }^{142}$

In sum, the sale of a good that embodies a patent exhausts that patent as to that good. By contrast, if the good itself is not covered by a patent but some complement to the product is, then patent infringement might apply. ${ }^{143}$ The impact complicates a firm's calculus in deciding whether to declare that a patent is "standard essential." Under the operating rules of most standard-setting organizations, individual participants declare which of their patents are standardessential. ${ }^{144}$ Until litigation arises, that decision is ordinarily subjected to very little review. That is, for the general run of SEPs no one does a thorough vetting of the patent in order to determine that it really is essential. Further, no one typically inquires into validity, and non-litigation related searches are uncommon. . $^{45}$

139. Leitch Mfg. Co. v. Barber Co., 302 U.S. 458 (1938); see also Mercoid Corp. v. Mid-Continent Inv. Co. (Mercoid I), 320 U.S. 661, 665 (1944) (referencing some exhaustion decisions, including Adams and Motion Picture Patents, but only for the proposition that patents must be limited to the terms of the grant).

140. 15 U.S.C. $\$ 271$ (c) (2012).

141. Dawson Chem. Co. v. Rohm \& Haas Co., 448 U.S. 176 (1980). The contributory infringement defendant sold the unpatented chemical in a container that bore instructions for its application, and following the instructions effectively practiced the plaintiff's method. Id. at 186.

142. By contrast, in Univis the patentee owned patents that covered both the bifocal lens blanks at issue and the process for grinding them. As a result, exhaustion applied. See United States v. Univis Lens Co., 316 U.S. 241, 246-47 (1942). Because the blanks were covered by patents the sale of the blanks exhausted those patents. See 10 PHILLIP E. AREEDA \& HERBERT HOVENKAMP, ANTITRUST LAW $\$ 1782 d$ (4th ed. forthcoming 2018).

143. Assuming, of course, that it is not also exhausted by sale of the complement.

144. See Evaluation of LTE Essential Patents Declared to ETSI, CYBER CREATIVE INST. 5 (2013), http://www.cybersoken.com/file//te03EN.pdf [http://perma.cc/3WSZ-QXK2].

145. Id. In fact, one of the issues in the ongoing litigation between Qualcomm and Apple plus its licensees is whether Qualcomm is simply entitled to a royalty on its portfolio of standard- 
The question whether to declare a patent "standard-essential" involves a tradeoff. By making the declaration, the patentee is presumptively entitled to participate in FRAND royalties, but under the FRAND agreement, it must also agree to license the patent on reasonable and nondiscriminatory terms and also to license all takers under the standard, whether or not they are competitors. Further, FRAND will very likely limit the size of the royalties. If the patentee withholds a relevant patent from a SEP declaration, however, then it will always be able to file an infringement action against any infringer and obtain whatever damages the court orders, but it would have to prove 'both validity and infringement, and that the patent was not exhausted by sale of a good. Notwithstanding these tradeoffs, however, it appears that "over declaring" of SEPs is relatively common, ${ }^{146}$ as Apple alleges of Qualcomm. ${ }^{147}$

It might be possible for a patentee to show both that a particular patent was standard-essential to a particular technology, but also that this particular patent did not read on a particular device intended for the standard in question. That is, the fact that a patent has been declared essential does not necessarily mean that it is essential for every implementation of a particular standard. ${ }^{148}$ The two products might be perfect or at least strong complements. For example, one needs both a toaster and bread to make toast, but the sale of a loaf of bread would certainly not exhaust a patent on the heating element of the toaster.

According to allegations by the Federal Trade Commission and Apple, many of which Qualcomm disputes, Qualcomm is attaching tying and quasiexclusive dealing obligations to its technology, most of which is subject to patents that it has also declared to be standard-essential. To the extent it is seeking to enforce these restrictions via patent infringement suits against manufacturers using devices reading on its SEPS, however, exhaustion very likely prevents it from proceeding. At this writing, the litigation is in the pleading

essential patents, or whether the courts must go through the patents individually in order to determine validity and infringement. See Qualcomm, Inc. v. Apple, Inc., No. 3:17-cv-01010-GPC-MDD, 2017 WL 3966944 (S.D. Cal. Sep. 7, 2017) (denying preliminary injunction pending resolution of this issue); see also Mark A. Lemley, Intellectual Property Rights and Standard-Setting Organizations, 90 CALIF. L. REV. 1889 (2002). As a general matter, a significant percentage of litigated Standard Essential Patents are found to be invalid. See RPX Corp., Standard Essential Patents: How do they Fare? (2014), http:// www.rpxcorp.com/wp-content/uploads/2014/01/Standard-Essential-Patents-How-Do-They-Fare.pdf [http://perma.cc/B2YT-P73Z] (finding win rates of twenty-to-forty percent but not distinguishing invalidity from infringement).

146. See Robin Stitzing et al., Over-Declaration of Standard Essential Patents and Determinants of Essentiality (Working Paper Mar. 31 2017), http://papers.ssrn.com/sol3/papers.cfm ?abstract_id=2951617 [http://perma.cc/MV5P-U447].

147. Qualcomm Complaint, supra note 136, ๆ 33-34 \& n.2; see also In re Qualcomm Antitrust Litig., No. 17-MD-02773, 2017 WL 5235649 (N.D. Ca. Nov. 10, 2017) (sustaining some of third party licensees claims against Qualcomm and dismissing Sherman Act claim for damages, but not a California Cartwright Act claim).

148. See id. ๆ 35. 
stage, with one denial of Qualcomm's request for a preliminary injunction and one court's refusal to dismiss some portions of a private lawsuit. ${ }^{149}$

\section{B. Exhaustion, Tying, and Misuse}

Historically, patent exhaustion was liberally applied to patent ties, provided that the tying product was sold. ${ }^{150}$ In these cases the infringement plaintiff, as in Impression Products, sold a patented tying product (whether projector, ice box, or phonograph) subject to a license condition requiring the purchaser to use the patentee's tied product (films, dry ice, or phonograph needles). These cases simultaneously found both exhaustion and became the historical basis for the development of the patent "misuse" doctrine.

The patent "misuse" doctrine eventually went further than simple exhaustion. Under the exhaustion rule, the patentee could not enforce a post-sale restriction on a patented product once the product had been sold. The unanimous Supreme Court decision in Suppiger went much further. ${ }^{151}$ Suppiger owned patents on a machine that injected salt into canned food as it was being processed. The company also required lessees of its machines to use its own salt tablets. ${ }^{152}$ Exhaustion would have prevented it from enforcing that tie by an infringement action against purchasers, although not lessees, of the machine. The infringement suit in question was not one against users to enforce the tying condition, however. Rather, it was a straightforward patent infringement action against a rival who had made an infringing machine. The infringement defendant successfully argued that, as long as Suppiger was misusing its own patents by tying, it could not enforce these patents against anyone-not even against someone who was not injured by the tie. Indeed, to the extent that Suppiger's salt tie was onerous to users of its machine, they would have switched to Morton, thus making Morton a beneficiary rather than a victim of the tie.

149. Judge Koh has refused to dismiss the FTC's complaint, which was brought under Sherman Act standards. FTC v. Qualcomm, Inc., No. 17-CV-00220, 2017 WL 2774406 (N.D. Cal, June 26, 2017); see also Qualcomm, Inc. v. Apple, Inc., No. 3:17-cv-01010, 2017 WL 3966944 (S.D. Cal. Sep. 7,2017 ) (denying Qualcomm a preliminary injunction compelling royalty payments); Jorge L. Contreras, Technical Standards, Standard-Setting Organizations and Intellectual Property: A Survey of the Literature, in 2 RESEARCH HANDBOOK ON THE ECONOMICS OF INTELLECTUAL PROPERTY LAW (Peter S. Menell \& David Schwartz eds., forthcoming 2018) (discussing the relationship between FRAND standards, downstream licensing, and exhaustion); In re Qualcomm Antitrust Litig., No. 17-MD-02773, 2017 WL 5235649 (N.D. Cal. Nov. 10, 2017) (denying action in a challenge to Qualcomm's alleged tying of its standard-essential patents to its handsets under the Sherman Act because plaintiffs were indirect purchasers, but approving it under California's Cartwright Act, which permits indirect purchaser damages suits).

150. E.g., Carbice Corp. of Am. v. Am. Patents Dev. Corp., 283 U.S. 27 (1931); Motion Picture Patents Co. v. Universal Film Mfg. Co., 243 U.S. 502 (1917); Straus v. Victor Talking Mach. Co., 243 U.S. 490 (1917).

151. Morton Salt Co. v. G.S. Suppiger Co., 314 U.S. 488 (1942). The Court was unanimous except for Justice Owen Roberts, who did not participate.

152. Morton Salt, 314 U.S. at 491-92. 
In any event, patent exhaustion did not appear to apply for two reasons. First, the machines were leased rather than sold. Second, the infringement action was not one to enforce the tying condition. Nevertheless, the Supreme Court held that the situation was "fundamentally the same" as those cases implicating patent exhaustion. ${ }^{153}$ The Seventh Circuit below had approved the infringement suit after finding that the tie did not violate Section 3 of the Clayton Act because it did not substantially lessen competition. ${ }^{154}$ In reversing, the Supreme Court found it unnecessary to decide the Clayton Act question because both "misuse" and patent exhaustion applied to defeat the tying restriction. ${ }^{155}$

Five years after Suppiger, the Supreme Court expanded Clayton Act antitrust liability to reach a similar tie, effectively eliminating the market power and effects requirements by holding that market power could be presumed from the simple fact that the salt-injecting machine was patented. ${ }^{156}$ This combination of exhaustion, misuse, and antitrust enabled an aggressive anti-tying regime that condemned competitively harmless ties for a half century. In 1988, Congress pushed back with the Patent Misuse Reform Act, and more recently, the Supreme Court overruled the International Salt presumption of market power from the existence of a patent. ${ }^{157}$ Impression Products represents a course reversal, once again making a certain class of patent ties unenforceable per se.

\section{Tying and the Patent Misuse Reform Act}

One provision in the Patent Misuse Reform Act, enacted in 1988, was intended to permit patent owners to enforce patent ties unless they are shown to be anticompetitive. Relying heavily on that Act, the Supreme Court's Illinois Tool Works decision reversed the market power presumption of International Salt, thus limiting antitrust illegality to situations where market power can be shown by traditional means. ${ }^{158}$ So the Act clearly reduced the reach of both "misuse" doctrine and antitrust to such ties. But what about exhaustion? The Supreme Court ignored the statute in Impression Products.

The Patent Misuse Reform Act embraces a "conditional" approach to patent ties, similar to the one that the Impression Products decision rejected. ${ }^{159}$ Section (d)(4) of that statute provides that no patent owner shall be denied relief in an infringement or contributory infringement lawsuit because it

\footnotetext{
153. Id. at 493 (citing numerous patent and copyright exhaustion cases).

154. G.S. Suppiger Co. v. Morton Salt Co., 117 F.2d 968 (7th Cir. 1941)

155. Morton, 314 U.S. at 494.

156. Int'l Salt Co. v. United States, 332 U.S. 392 (1947).

157. Ill. Tool Works, Inc. v. Indep. Ink, Inc., 547 U.S. 28 (2006).

158. On the impact of Illinois Tool Works, see 2B PHILLIP E. AREEDA \& HERBERT HOVENKAMP, ANTITRUST LAW $\$ 518$ (4th ed. 2014).

159. 35 U.S.C. $§ 271$ (d) (2018).
} 
[c]onditioned ... the sale of the patented product on the ... purchase of a separate product ... unless, in view of the circumstances, the patent owner has market power in the relevant market for the patent or patented product on which the license or sale is conditioned. ${ }^{160}$

Section (d)(4) applies only to tying arrangements, but it unambiguously provides that a person who conditions the "sale" of a patented product on the buyer's purchase of a second product may enforce that requirement by means of a patent infringement action, at least so long as the patent holder has not been shown to have market power in the primary product. ${ }^{161}$

The Impression Products Court did not consider whether $\S 271(\mathrm{~d})(4)$ operated as an exception to patent exhaustion for tying arrangements, however, very likely because the language of the statute does not fit very well with what Lexmark did in that case. It did not require purchasers of its patented printers to purchase its patented cartridges. Rather, it required a certain class of customers to return their empty cartridges to Lexmark and forbade others from refilling them. The result of this policy, if completely effective, would have been to steer Lexmark printer users to Lexmark cartridges, but to the extent the statutory language contemplates an express tying condition, the Lexmark condition did not reveal it.

Nevertheless, Lexmark might have avoided the Impression Products result simply by writing a somewhat different condition, designed to fall within $\S$ 271(d)(4). If it had fixed a notice to each printer and each cartridge to the effect that use of anything other than original equipment Lexmark cartridges in the printer constituted patent infringement, that provision would have fallen within $\S 271(\mathrm{~d})(4)$, rendering it immune from exhaustion challenge. Under a different provision of $\S 271$, a refiller would be guilty of contributory infringement, provided that the refilled cartridge was not capable of substantial noninfringing uses. ${ }^{162}$ As noted previously, Lexmark's small market share would make a finding of sufficient market power unlikely. ${ }^{163}$

160. Id.

161. See Herbert Hovenkamp, Post-Sale Restraints and Competitive Harm: The First Sale Doctrine in Perspective, 62 N.Y.U. ANN. SURV. AM. L. 487, 535 (2011) (making this observation).

162. That act would be covered by 35 U.S.C. $\$ 271$ (c) (2018):

Whoever offers to sell or sells within the United States or imports into the United States a component of a patented machine, manufacture, combination or composition, or a material or apparatus for use in practicing a patented process, constituting a material part of the invention, knowing the same to be especially made or especially adapted for use in an infringement of such patent; and not a staple article or commodity of commerce suitable for substantial noninfringing use, shall be liable as a contributory infringer.

See also Dawson Chem. Co. v. Rohm \& Haas Co., 448 U.S. 176, 185-86 (1980) (finding infringement when patentee's component was not capable of substantial noninfringing uses); Lucent Tech., Inc. v. Gateway, Inc., 580 F.3d 1301, 1320-21 (Fed. Cir. 2009) (finding contributory infringement when defendant's complementary product did not have substantial noninfringing uses); I4I Ltd. P'ship v. Microsoft Corp., 598 F.3d 831, 851 (Fed. Cir. 2010) (holding similar), aff'd on other grounds, 564 U.S. 91 (2011).

163. See supra note 21 and accompanying discussion. 


\section{Assessing Unreasonable Patent Exhaustion}

An important difference between patent exhaustion and antitrust rules on restricted distribution is the method of enforcement. While federal antitrust law applies to both contract enforcement and enforcement via infringement actions, the exhaustion rule applies only to the latter. There may be good reasons for adopting narrower rules for infringement actions, which can reach people not in privity of contract. Nevertheless, that does not justify a per se prohibition such as the one the Court adopted in Impression Products. In some circumstances, enforcement via infringement suits may be a more efficient way of organizing distribution than enforcement by breach of contract actions. Fashioning an appropriate rule requires appreciation of just how many such situations there are, as well as the social cost of a rule that is too harsh or too lenient.

Further, patent law may have concerns that reach beyond antitrust law. As a result, the Mallinkrodt rule permitting infringement actions upon a clearly stated condition unless the condition constitutes an antitrust violation or patent misuse seems excessively tolerant. ${ }^{164}$ For example, infringement suits can catch the unaware by surprise. This can be remedied by a judicial amendment requiring effective and timely notice. ${ }^{165}$ Overbroad enforcement rights may lead to splintering of royalty obligations, producing high transaction costs and double marginalization. ${ }^{166}$ Effects may differ depending on the type of remedy that the patentee is able to obtain, whether damages or an injunction. Some conditions apply only once, typically to end users, while others get passed down the distribution chain. As a general proposition, none of these effects violates the antitrust laws, even though they might reduce economic welfare.

Even the duration issue is less categorical and more complex than it first appears. As noted previously, the common law was generally more willing to enforce restraints that were limited in time. One must always ask, however, time in relation to what? A 100-year restraint such as the rule against perpetuities might permit seems relatively short in relation to family interests in land. By contrast, a use restraint on a reusable printer cartridge that lasts for the remaining life of its patents - say, ten years - may be as good as forever. The question is the relationship between the duration of the restraint and the relevant life of the product to which it applies. Some post-sale restraints, such as the restrictions on re-use or refilling in Mallinkrodt and Impression Products operate effectively for the life of the product to which they are attached. They operate by shortening the usable life of the product.

164. See Mallinkrodt, Inc. v. Medipart, Inc, 976 F.2d 700, 701 (Fed. Cir. 1992) (permitting a clearly stated condition that accompanies a sale to be enforced via an infringement action unless the condition violates the antitrust laws or constitutes patent misuse); see also Wentong Zheng, Exhausting Patents, 63 UCLA L. REV. 122 (2016) (offering a similar proposal).

165. See Hovenkamp, supra note 161 , at 516-522

166. Id. at 513-15. 
The best way to address these problems is not through antitrust law, but rather by development of a federal common law of post-sale patent restraints that is more nuanced than is reflected in existing Supreme Court doctrine, but that reaches further than antitrust. The fact that the restraints come in a large variety suggests that a common law judge made approach would be better than a statute. The suggestions offered here are not intended to be exhaustive, but rather illustrative of the fact that post-sale restraints come in many different kinds, with differing effects on welfare, competition, or innovation. To the extent manageable, an effective set of enforcement rules for such restraints must take these differences into account. In the process, it would make patent law more sensitive to the variety of market situations in which patents are licensed.

One important consideration in the development of such doctrine is the effect of the distribution restraint when enforcement is limited to breach of contract suits. When simple contract enforcement is likely to satisfy the patentee's legitimate distribution needs, the case for enforcement via infringement actions is much less important. Accordingly, a court can feel free to apply exhaustion. This query would result in exhaustion in many but not all situations. In Impression Products itself for example, the Court acknowledged that contract enforcement mechanisms were inadequate. ${ }^{167}$ In that case, application of exhaustion was ill advised without a showing that some other harm to competition or innovation was in prospect.

Contractual enforcement of resale price maintenance rules, another frequent subject of exhaustion litigation, is usually accomplished quite easily, at least in two-stage distribution systems. Cheating sales are ordinarily detectable. Prices must be advertised in order to be effective, and rival dealers can be trusted to complain. ${ }^{168}$ In sum, violations of resale price maintenance provisions are generally easier to detect than violations of tying arrangements imposed on consumers. As a result, the effectiveness of contract law suggests that the courts can feel freer to apply exhaustion.

Restrictions on the resale of exported and re-imported goods, relevant in both Kirtsaeng and Impression Products, raise different issues. Sellers often engage in third-degree price discrimination ${ }^{169}$ as between domestic and foreign sales-a strategy that can be frustrated by arbitrage. For example, Kirtsaeng might purchase books at a low price in Asia in order to import and resell them in the United States at a higher price. Third-degree price discrimination can increase welfare if it increases output, ${ }^{170}$ and in many such cases, the foreign sales are an output increasing strategy. That is, consumer elasticity of demand is

\footnotetext{
167. Impression Prods., Inc. v. Lexmark, Int'l, Inc., 137 S. Ct. 1523, 1530 (2017).

168. See 7 PHILLIP E. AREEDA \& HERBERT HOVENKAMP, ANTITRUST LAW I 1453 (4th

ed. 2017)

169. In third-degree price discrimination, a seller pre-selects different groups of customers based on its assessment of differential willingness-to-pay and prices accordingly.

170. See, e.g., Simon Cowan, Welfare-Increasing Third-Degree Price Discrimination, 47 RAND J. ECON. 326 (2016).
} 
higher in the foreign country, and the seller can make those sales only at a lower price. In a well-functioning price discrimination program, it need not lose higher price domestic sales in order to make the foreign sales. That policy will be defeated, however, if a foreign purchaser such as Kirtsaeng can arbitrage the books back into the domestic market. In that case, an exhaustion rule might make the publisher decide not to sell books in another country at a lower price at all. The best economic policy is to permit the IP rights holder to discriminate. An immediate purchaser from the publisher would have privity of contract, so an infringement suit would be unnecessary. ${ }^{171}$ Detection might be an issue, but not one that would distinguish infringement actions from contract actions. A purchaser two or three steps removed would not have privity, however. Of course, a notice restricting resale territories could readily be placed inside the book, effectively communicating it to more remote resellers. ${ }^{172}$

An important requirement of any federal common law of post-sale patent restraints should be effective and timely notice to prospective infringers. Although patent infringement does not require that the infringer have prior notice of infringement or even of the patent's existence, that is hardly the same thing as notice of a particular restriction that has been imposed in a patent license. To the extent a post-sale restraint is likely to catch infringement defendants who are unaware, enforcement should be denied. By contrast, if notice is given and effective to all downstream parties, including those not in privity with the rights holder, then enforcement is more appropriate.

Federalism concerns may also be appropriate when a post-sale restraint creates inconsistency with state law. Under the Supremacy Clause, the requirements for federal patent infringement trump inconsistent state law, but a judge-made common law of post-sale restraints could apply comity so as to give state law due regard. For example, the manufacturer of a patented outdoor grill might impose a condition charging purchasers a higher price if they do not use its own refillable propane tanks. But those tanks may be banned by state law as dangerous. A federal court might well apply common law powers to hold that such an enforcement action pushes the federal law of patent infringement too far into territory that should be reserved to the states.

Lest this strike some as inconsistent with the supremacy of federal law, it is worth noting that federal antitrust policy makes these tradeoffs all the time.

171. In Kirtsaeng v. John Wiley \& Sons, Inc., 568 U.S. 519, 526-527 (2013), Kirtsaeng asked friends and relatives in Thailand to purchase books oversees at the lower price and mail them to him while he studied in the United States. He then resold the books on eBay or other websites. In that case the publisher and Kirtsaeng were not in privity.

172. Cf. Bobbs-Merrill Co. v. Straus, 210 U.S. 339 (1908). The restriction was printed in each copy of the book just behind the title page: "The price of this book at retail is $\$ 1$ net. No dealer is licensed to sell it at a less price, and a sale at a less price will be treated as an infringement of the copyright. The Bobbs-Merrill Company." Id. at 341. Such a notice, unless removed, would be warning to anyone downstream, no matter how removed from the publisher. The foreign-distributed Wiley books in Kirtsaeng also contained a printed notice in each foreign-sold book restricting the location of sale. See 568 U.S. at 525-26. 
For those activities in or affecting interstate commerce, the Sherman Act could trump thousands of state measures that regulate rates or exclude certain firms from markets. But antitrust policy does not follow a course of knocking all state economic regulation to the side simply because Congress has the power to do so. Instead, it looks for ways to make federal antitrust policy work in tandem with state regulation. That entails that sometimes federal supremacy reigns, but in other cases, state or local regulation prevails. ${ }^{173}$ Further, the set of rules that makes these determinations-principally the "state action" doctrine ${ }^{174}$-are essentially judge made and highly fact specific.

\section{Conclusion}

The Impression Products patent exhaustion rule is a blunt instrument in relation to the justifications offered for it. In its favor, a rule of per-se-exhaustionupon-sale is simply stated and perhaps easily understood. ${ }^{175}$ Because it is so categorical, however, it fails to distinguish harmful uses of post-sale restraints from the large number that are beneficial. The antitrust law of restricted distribution began in a similar place, adopting categorical per se rules that, as our understanding of the economics of restricted distribution changed, eventually gave way to more nuanced treatment under the rule of reason. Even a quick examination of the types of restraints imposed in exhaustion cases indicates that they are used for many different purposes and with different effects. The Impression Products decision was wrong to make these differences irrelevant.

173. For a survey of such situations, see 1 PHILLIP E. AREEDA \& HERBERT HovenKAMP, ANTITRUST LAW, Ch. 2B (4th ed. 2013) (federal antitrust law); id. ch. 24 (3d ed. 2012) (state antitrust law); see also Wayne D. Collins, Trusts and the Origins of Antitrust Legislation, 81 FORDHAM L. REV. 2279, 2340 (2013) ("[T]he backers of the Sherman Act assured the floor of the Senate that they were merely seeking to enable federal courts to apply the common law to anticompetitive business activities and early federal cases are full of citations to English and state common law.").

174. See AREEDA \& HOVENKAMP, supra note 173, at chs. 1A, 2 B-3.

175. But see Straus v. Victor Talking Mach. Co., 243 U.S. 490, 498 (1917), in which the patentee attempted to evade the first sale doctrine by nominally "licensing" phonograph machines to dealers, who were authorized to relicense them to consumers even though the transactions bore all the indicia of a sale, including assignment of all risk of loss or nonsale to the acquiring dealers. Further, the "royalty" stipulated in the agreement was an upfront lump sum of $\$ 200$, suggesting that it was a disguised sale. The Court concluded that:

Courts would be perversely blind if they failed to look through such an attempt as this "License

Notice" thus plainly is to sell property for a full price, and yet to place restraints upon its further

alienation, such as have been hateful to the law from Lord Coke's day to ours, because obnoxious to the public interest.

Id. at 500-01. The case involved both resale price maintenance and tying. On the latter, users were required to use only needles and phonograph records supplied by Victor. This suggests that Victor very likely had an enforcement problem similar to the one that the Court recognized in Impression Products. See supra notes 23-24 and accompanying discussion. 